\title{
Coronaviruses and Nature's Pharmacy for the Relief of Coronavirus Disease 2019
}

\author{
Kazhila C. Chinsembu ${ }^{1}$ (D)
}

Received: 3 August 2020 / Accepted: 14 September 2020 / Published online: 6 October 2020

(C) Sociedade Brasileira de Farmacognosia 2020

\begin{abstract}
Current challenges to the treatment of coronavirus disease 2019 should open new prospects in the search for novel drugs from medicinal plants and other natural products. This paper provides details of natural agents that inhibit human coronavirus entry into cells, general replication, and specific chymotrypsin-like protease $\left(3 \mathrm{CL}^{\mathrm{pro}}\right)$-mediated replication. Medicinal plants, fungi, and marine organisms as remedies for human coronaviruses in China, Lebanon, Malaysia, Singapore, and South Africa are described. Common species include Alnus japonica (Thunb.) Steud., Artemisia annua L., Artemisia apiacea Hance, Astragalus membranaceus (Fisch.) Bunge, Cinnamomum cassia (L.) J.Presl, edible brown algae Ecklonia cava Kjellman, Euphorbia neriifolia L., Glycyrrhiza glabra L., Lonicera japonica Thunb., Pelargonium sidoides DC., Polygonum cuspidatum Siebold \& Zucc., Sanguisorba officinalis L., Scutellaria baicalensis Georgi, Toona sinensis (Juss.) M.Roem., and Torreya nucifera (L.) Siebold \& Zucc. At least fifty natural compounds, including alkaloids, flavonoids, glycosides, anthraquinones, lignins, and tannins, which inhibit various strains of human coronaviruses, are presented. Given the scarcity of efficacious and safe vaccines or drugs for coronavirus disease 2019, natural products are low-hanging fruits that should be harnessed as the new global frontier against severe acute respiratory syndrome coronavirus 2 .
\end{abstract}

Keywords COVID-19 $\cdot$ Human respiratory infection $\cdot$ Natural inhibitors

\section{Introduction}

Coronaviruses (CoVs) cause acute and chronic respiratory, enteric, and central nervous system diseases in many species of animals including humans. While the history of CoVs dates as far back as the 1940s, identification of the first human $\mathrm{CoVs}(\mathrm{HCoVs})$ as causative agents of mild respiratory infections was reported in the 1960s. These HCoVs were named human CoV 229E (HCoV-229E) and HCoV-OC43 (Pillaiyar et al. 2020). The replication and pathogenesis of CoVs were actively studied by virologists in the 1970 s, leading to the discovery of four other human $\mathrm{CoVs}$, namely HCoV-Hong Kong University 1 (HCoV-HKU1), human coronavirusNL63 (HCoV-NL63), severe acute respiratory syndrome (SARS)-CoV, and Middle East respiratory syndrome (MERS)-CoV (Pillaiyar et al. 2020).

Kazhila C. Chinsembu

kchinsembu@unam.na

1 Faculty of Science, Department of Biological Sciences, University of Namibia, Private Bag 13301, Windhoek, Namibia
SARS is a highly contagious and often fatal respiratory infection. HCoV-229E, HCoV-OC43, HCoV-NL63, and $\mathrm{HCoV}-\mathrm{HKU} 1$ are ubiquitous and cause approximately onethird of common cold in humans. HCoV-229E, HCoVOC43, HCoV-NL63, and HCoV-HKU1 strains are usually associated with mild, self-limiting upper respiratory tract infections, such as the common cold (Andersen et al. 2020). However, subtypes HCoV-229E, HCoV-OC43, HCoVHKU1, and HCoV-NL63 can cause life-threatening pneumonia and bronchitis in the elderly and immunologically compromised individuals including those undergoing chemotherapy and persons living with HIV/AIDS.

Indeed, before the discovery of SARS-CoV, two coronaviruses, $\mathrm{HCoV}-229 \mathrm{E}$ and $\mathrm{HCoV}-\mathrm{OC} 43$, were known to infect humans, but they caused only selflimiting upper respiratory tract infections $(30 \%$ of the common colds), and had never been reported to cause severe illness (Kuba et al. 2005). SARS-CoV caused a global epidemic from November 2002 to 2003; about 8422 people were infected in 32 countries, 916 persons died, and the fatality rate was $10-15 \%$. Analysis of the full sequence of SARS-CoV, which is about $29.7 \mathrm{~kb}$ in 
length, reveals that it is a large, single-stranded, positivesense RNA virus (Keum and Jeong 2012).

In 2013, MERS-CoV also triggered an epidemic in the Middle East and a major outbreak in South Korea occurred in May-June 2015 (Kim et al. 2017a). With a case-fatality rate of $35.5 \%$, MERS-CoV is heavily endemic in dromedary camels and causes lower respiratory tract infections in humans (Kim et al. 2017a). Although the SARS-CoV epidemic had been under control for years, Wang et al. (2017) warned that re-emergence of this threatening infection posed a possible global risk as potentially new strains of SARS-CoV would be more dangerous than the previous ones.

Toward the end of 2019 and the beginning of 2020, multiple human cases of a new viral infection were reportedly linked to the Huanan Seafood Wholesale "wet" Market (South China Seafood City Food Market) in Wuhan, China (Li et al. 2020; Zhang et al. 2020). On 7 January 2020, the new virus was identified as a novel coronavirus and officially named by the World Health Organization as 2019-nCoV ( $\mathrm{Li}$ et al. 2020). On 20 January 2020, the National Health Commission of China confirmed the human-to-human transmission of 2019-nCoV with its presenting common symptoms such as fever, tiredness, dry cough, shortness of breath, and pneumonia (Elfiky 2020), and less common signs as diarrhea, conjunctivitis, headache, loss of taste or smell, and rash on skin or discoloration of fingers and toes. The World Health Organization also recognized $2019-\mathrm{nCoV}$ as the causative agent of the coronavirus disease 2019 (COVID-19). The 2019-nCoV was later named severe acute respiratory syndrome coronavirus 2 (SARS-CoV-2) by the International Committee on Taxonomy of Viruses, Coronaviridae Study Group (Ling 2020).

A phylogenetic analysis found a bat origin for the SARSCoV-2 (Lu et al. 2020; Wan et al. 2020). Yang et al. (2020) reported that SARS-CoV-2, formerly known as 2019-nCoV, the causative pathogen of COVID-19, had rapidly spread across China and around the world, causing an outbreak of acute infectious pneumonia. The spread of SARS-CoV-2, a new highly contagious and lethal strain of $\mathrm{HCoVs}$, has now caused a global pandemic (Remuzzi and Remuzzi 2020). In the morning of 7 September 2020, Johns Hopkins University reported that there were over $26,994,442$ total confirmed cases and 880,994 deaths globally; over $6,189,488$ cases and 187,541 deaths were in the United States of America (USA). COVID-19 has spread more rapidly due to increased global travel and adaptation of SARS-CoV-2 in every environment (Vellingiri et al. 2020).

Currently, the seven identified human coronaviruses (HCoVs) are SARS-CoV-2, MERS-CoV, SARS-CoV, HCoV-229E, HCoV-OC43, HCoV-NL63, and HCoVHKU1 strains (Andersen et al. 2020). Molecular evolutionary analysis shows that all $\mathrm{HCoVs}$ originate in animals; SARSCoV, MERS-CoV, HCoV-NL63, and HCoV-229E are derived from bats; $\mathrm{HCoV}-\mathrm{OC} 43$ and $\mathrm{HCoV}-\mathrm{HKU} 1$ are sourced from rodents (Forni et al. 2017). The 229E and NL63 strains of HCoVs belong to alpha coronaviruses while OC43, HKU1, SARS, MERS, and SARS-CoV-2 belong to beta coronaviruses (Elfiky 2020). Most people infected with SARS-CoV, MERS-CoV, and SARS-CoV-2 present with severe respiratory distress, and many of the infected succumb to coronavirus infection (Andersen et al. 2020).

Pillaiyar et al. (2020) reviewed recent developments in the discovery and development of synthetic drugs to treat HCoVs. However, these drugs have not achieved extended distribution for clinical application because they have not yet been tested in rigorous randomized controlled clinical trials (Ford et al. 2020). Zhou et al. (2020a, b) reported that there were no effective drugs targeting SARS-CoV-2. Yang et al. (2020) also stated no efficacious and safe antiviral drugs or vaccines were available for the treatment of this sudden and lethal disease. Supportive care and non-specific treatment to ameliorate COVID-19 symptoms of the patient are the main options available.

Remdesivir, produced by the company Gilead, shows $\mathrm{EC}_{90}$ of $1.76 \mu \mathrm{M}$ against SARS-CoV-2 in vitro (Elfiky 2020). On 1 May 2020, remdesivir was granted approval by the US Food and Drug Administration for emergency use in the treatment of COVID-19 patients. An inhibitor of the enzyme RNAdependent RNA polymerase (RdRp) involved in HCoV replication, the drug reduced mortality from 11 to $8 \%$ and duration of symptoms from 15 to 11 days. However, in comparison with the placebo, remdesivir's reduction of patient mortality was not significantly different.

Due to the absence of conventional therapies, Yang et al. (2020) reported that more than $85 \%$ of SARS-CoV-2-infected patients in China were treated with traditional Chinese medicine (TCM). During the 2002 to 2003 outbreak, TCM was also used as a supplementary treatment of severe laboratoryconfirmed conditions of SARS (Hsu et al. 2006a). Along this trajectory, the aim of the current review is to provide an update on the bioactivity functions of medicinal plants and other natural products that have previously been used to treat coronaviruses. In the short term, knowledge of these natural products may be significant in the relief of COVID-19 symptoms. In the long term, natural products that alleviate COVID19 symptoms may be used in the search for novel drugs against SARS-CoV-2. In the face of current challenges to the treatment of COVID-19, data presented in this review may help to reimagine a new future where natural products are the new frontier for more efficacious and low-cost SARS$\mathrm{CoV}-2$ inhibitors. The goal is to create a strong bioprospecting pipeline from which pharmaceutical companies can advance the discovery and repurposing of COVID-19 drugs from current medicinal plants and other natural products.

To prevent author bias, this review was carried out using a comprehensive and systematic data mining approach similar 
to that used by Chinsembu (2019). To obtain pertinent literature, the key words "SARS" and "medicinal plants" were concomitantly searched in Google Scholar, Elsevier's payto-view service Science Direct, Scopus, Scielo, and PubMed Central, the US National Library of Medicine's digital archive of biomedical and life sciences journal literature. Literature sources included peer-reviewed journal articles and refereed books. Medicinal plants, mushrooms, algae, and sponges with anti-SARS activity were included. Wherever possible, active compounds and anti-SARS profiles mainly half maximal inhibitory concentration $\left(\mathrm{IC}_{50}\right)$ and effective concentration $\left(\mathrm{EC}_{50}\right)$ were recorded. Inclusion criteria included plants, fungi, and marine organisms, namely algae and sponges. Exclusion criteria included animal products. Countries reported in the review were those where primary data were collected; hence, geographical scope was not deliberately selected. The International Plant Names Index (http://www.ipni.org) and The Plant List (http://www.theplantlist.org) were used to verify names of plant species.

\section{Discussion}

\section{Entry Inhibitors}

The spike protein, a type I membrane-bound protein, is essential for SARS-CoV attachment to the host cell receptor angiotensin-converting enzyme 2 (ACE2). In general, SARS-CoV entry starts with the attachment of the virus to its specific receptor ACE2 on the host cell surface (Keyaerts et al. 2007). Binding of ACE2 then induces the viral envelope protein to undergo conformational changes that mediate fusion between SARS-CoV and host cell membranes. The spike protein is responsible for these two steps in the coronavirus entry process (Keyaerts et al. 2007). A member of the C-type lectin superfamily, dendritic cell (DC)-specific ICAMgrabbing non-intergrin (DC-SIGN), a molecule designated as CD209, binds to surface proteins of SARS-CoV, consequently facilitating viral entry (Liu et al. 2015). SARS-CoV spike protein contains a number of $N$-linked glycosylation sites that modulate binding to the DC-SIGN receptor on DC (Zhang et al. 2007). SARS-CoV binding to DC-SIGN is required for DC infection and target cell trans-infection. DCSIGN plays an important role in mediating DC adhesion and internalization of SARS-CoV.

Antiviral agents from plants generally block virus entry and membrane fusion (Hsieh et al. 2004). De Clercq (2005) suggested that it was feasible to develop SARS-CoV fusion inhibitors analogous to enfuvirtide, a linear 36-amino acid synthetic peptide marketed under the trade name Fuzeon, an approved anti-HIV drug that inhibits the entry of the virus into cells. SARS-CoV entry inhibitors fall into several categories. The first group consists of inhibitors that bind to the ACE2 receptor, the second class comprises entry inhibitors that bind to the virus and prevent it from interacting with its receptors, and the third set of inhibitors can obstruct the conformational changes thus thwarting SARS-CoV fusion with the target cells (Keyaerts et al. 2007). An effective inhibitor of SARS-CoV, the medicinal basidiomycete Ganoderma lucidum (Curtis) Karst. contains ganoderic acid F, a lanostane triterpene that acts as an inhibitor of ACE2 receptor $\left(\mathrm{IC}_{50} 4.7 \times 10^{-6} \mathrm{M}\right.$ ) (Morigiwa et al. 1986).

\section{Lectins as Biologics}

Lee (2019) asserts that lectins have emerged as a new class of antiviral biologic drugs or biologics by taking advantage of a unique glycosylation pattern only found on the surface of viruses. Lectins, a group of proteins with carbohydrate recognition activity, recognize the SARS-CoV spike protein (Liu et al. 2015). Keyaerts et al. (2007) found prominent antiSARS-CoV activity among mannose-specific plant lectins. One of the most potent lectins against the SARS-CoVinduced cytopathicity is the mannose-specific plant lectin isolated from leek (Allium porrum L.) with an $\mathrm{EC}_{50}$ of $0.45 \mu \mathrm{g} / \mathrm{ml}$ and a selectivity index of $>222$. The $N$-acetyl glucosamine-specific lectins isolated from the stinging nettle (Urtica dioica L.) and from the tobacco plant (Nicotiana tabacum L.) were also markedly active against the SARS$\mathrm{CoV}$ with a selectivity index of $>77$ and $>59$, respectively (Kumaki et al. 2011). A mannose-specific lectin (agglutinin) of Hippeastrum striatum (Lam.) H.E.Moore prevented the penetration of SARS-CoV into Vero E6 cells $\left(\mathrm{EC}_{50}\right.$ $2.5 \mu \mathrm{g} / \mathrm{ml}$ at $4{ }^{\circ} \mathrm{C}$ ) (Keyaerts et al. 2007). SARS-CoV spike protein contains $12 \mathrm{~N}$-glycosylation sites and the sugars attached to four of these $N$-glycosylation sites have been identified (Zhou et al. 2010). Two of the four sugars were found to be high-mannose-type glycans and the other two showed complex glycan structures (Zhang et al. 2005). The potent anti-SARS-CoV activity of mannose-specific plant lectins is therefore attributable to the presence of high-mannose-type glycans in the SARS-CoV spike protein (Keyaerts et al. 2007; Zhou et al. 2010).

Many lectins from algae have antiviral activity. A highly potent broad-spectrum antiviral, griffithsin is a 121-amino acid red alga-derived lectin that binds to the terminal mannose residues of the asparagine $(N)$-linked Man 5-9 GlcNAc2 structures found on the envelope of SARS-CoV (Lee 2019). Initially identified as an anti-HIV-1 agent with $\mathrm{EC}_{50}$ of $0.43-0.98 \mathrm{nM}$, griffithsin isolated from the aqueous extract of the red algae Griffithsia corallinoides (L.) Trevisan found off the eastern shore of Chatham Island, New Zealand, is a $12.7-\mathrm{kDa}$ lectin that also inhibits SARS-CoV $\left(\mathrm{EC}_{50} 0.048-\right.$ $960 \mathrm{nM})$, various avian CoV subtypes ( $\left.\mathrm{EC}_{50} 0.032-0.57 \mathrm{nM}\right)$, bovine $\mathrm{CoV}\left(\mathrm{EC}_{50} 0.057 \mathrm{nM}\right)$, puffinosis $\mathrm{CoV}\left(\mathrm{EC}_{50}\right.$ 
$0.57 \mathrm{nM}$ ), and $\mathrm{HCoV}$ mutants with $\mathrm{EC}_{50}$ of $0.16 \mathrm{nM}$ (Mitchell et al. 2017).

\section{Protease Inhibitors}

Some viruses such as Ebola and SARS-COV use cathepsins, a family of proteases, to infect host cells (Huang et al. 2006). Inhibitors of cathepsin L prevent entry of SARS-CoV into target cells (Simmons et al. 2005). Unfortunately, many cathepsin inhibitors are non-selective (Zhou et al. 2016). Leupeptin (1), also known as $N$-acetyl-L-leucyl-L-leucyl-L-argininal, is protease inhibitor produced by actinomycetes and isolated from a strain of Streptomyces exfoliatus (Waksman and Curtis) Waksman and Henrici, which can inhibit cysteine, serine, and threonine peptidases. Simmons et al. (2005) showed that inhibitors of proteases such as leupeptin act as potent inhibitors of SARS-CoV entry into host cells. SARS-CoV spike protein-driven virus-cell fusion is inhibited by $\mathbf{1}$ (Simmons et al. 2011), which exhibited a dose-dependent inhibition of SARS-CoV infection (Zhou et al. 2011) $\left(\mathrm{IC}_{95} 15.2 \mu \mathrm{M}\right)$. This inhibition is the result of an absolute requirement in cell lines for endosomal processing of the SARSCoV spike protein by cathepsin L during entry into the target cell (Simmons et al. 2011). The oligopeptide antipain (2), an inhibitor of trypsin and papain, isolated from actinomycetes inhibited SARS-COV entry into host cells (Simmons et al. 2005).<smiles>CC(=O)N[C@@H](CC(C)C)C(=O)N[C@@H](CC(C)C)C(=O)N[C@@H](C=O)CCCNC(=N)N</smiles>

1<smiles>CC(C)[C@H](NC(=O)[C@H](CCCN=C(N)N)NC(=O)N[C@@H](Cc1ccccc1)C(=O)O)C(=O)N[C@@H](C=O)CCCN=C(N)N</smiles>

2

\section{Anthraquinone Derivatives}

Emodin (3) is a naturally occurring anthraquinone derivative and an active ingredient of medicinal plants including Rheum palmatum L., Rheum tanguticum Maxim. ex Balf., Polygonum cuspidatum Siebold \& Zucc., Polygonum multiflorum Thunb., Aloe vera (L.) Burm.f., Senna obtusifolia (L.) H.S.Irwin \&
Barneby (Dong et al. 2016; Zhou et al., 2020a, b), and Cassia tora L. Emodin inhibited SARS-CoV via the blockage of viral entry by binding to the spike proteins and interfering with SARSCoV 3CL ${ }^{\text {pro }}$ activity (Hyun et al. 2009). In assays involving SARS-CoV and HCoV-OC43, emodin in a dose-dependent manner significantly blocked the interaction between the SARS-CoV spike protein and ACE2 (a functional SARS-CoV receptor), inhibited the $3 \mathrm{a}$ ion channel ( $K_{1 / 2}$ value of about $20 \mu \mathrm{M}$ ), and stopped new coronavirus release (Dong et al. 2016; Ho et al. 2007). SARS-CoV-2 spike protein directly binds to the host cell surface ACE2 receptor facilitating virus entry and replication (Zhang et al. 2020). Corollary, emodin can be considered a potential lead therapeutic agent in the treatment of SARS-CoV-2 infection. Experimental data now suggest that combining emodin and the drug toremifene, a first-generation non-steroidal selective estrogen receptor modulator for the treatment of metastatic breast cancer, provides a potential therapeutic approach for SARS-CoV-2 (Zhou et al., 2020a, b).<smiles>Cc1cc(O)c2c(c1)C(=O)c1cc(O)cc(O)c1C2=O</smiles>

3

\section{Triterpene and Their Glycosides}

Terpenoids isolated from medicinal plants have attracted attention because many of them exhibit specific in vitro antiviral effect against SARS-CoV (Wen et al. 2007). Triterpenoids inhibit the entry of Ebola, Marburg, HIV, and influenza A viruses with distinct structure-activity relationships ( $\mathrm{Si}$ et al. 2018). These natural agents modulate a broad range of virus-host fusion functions via wrapping the heptad repeat 2 domain prevalent in viral envelopes. Euphorbia neriifolia L. produces 22 triterpenoids with stronger activity against $\mathrm{HCoVs}$ than actinomycin D (Chang et al. 2012).

Saikosaponins represent a group of oleanane derivatives, usually as glucosides, found in medicinal plants in the genera Bupleurum L., Heteromorpha Cham. \& Schltdl., and Scrophularia L. (Cheng et al. 2006). Saikosaponins A, B 2 C, and D demonstrated anti-HCoV-229E activity at concentrations of $0.25-25 \mu \mathrm{M}$, with the strongest activity being noted for saikosaponin $\mathrm{B}_{2}(\mathbf{4})\left(\mathrm{IC}_{50} 1.7 \pm 0.1 \mu \mathrm{M}\right)$ (Cheng et al. 2006). Since saikosaponin $\mathrm{B}_{2}$ blocks HCoV-229E attachment and penetration, it could be a novel lead for the development of a potential chemo-preventive agent for SARS-CoV infection (Cheng et al. 2006). Yang et al. (2020) reported that saikosaponins and glycyrrhizin from Toona sinensis (Juss.) M.Roem. had potent anti-SARS-CoV effects by inhibition of viral cellular entry, adsorption, and penetration. 


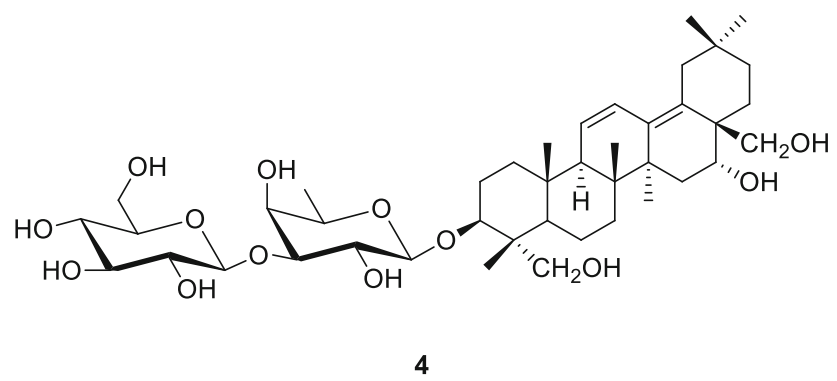

The licorice plant, Glycyrrhiza glabra L., was reported to have specific anti-SARS effects (Polansky and Lori 2020). Constituents of licorice include triterpenoids such as glycyrrhizin or glycyrrhizic acid (5). Glycyrrhizin (5) exerted very high antiviral activity and in vitro inhibition of SARS$\mathrm{CoV}\left(\mathrm{EC}_{50} 300 \mu \mathrm{g} / \mathrm{ml}\right)$ (Cinatl et al. 2003). Glycyrrhizin and its derivatives inhibited SARS-CoV replication in vitro (Baltina et al. 2015).

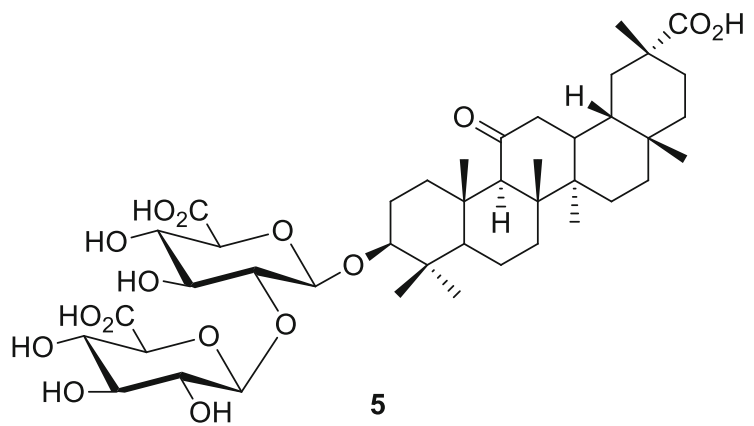

Ryu et al. (2010a) reported that 95\% methanolic extracts of the bark of Tripterygium regelii Sprague \& Takeda remarkably inhibited SARS-CoV 3CL $\mathrm{C}^{\text {pro }}$ activity ( $>70 \%$ inhibition at $30 \mu \mathrm{g} / \mathrm{ml}$ ) (Ryu et al. 2010a). The active compounds of T. regelii are four quinone-methide triterpenoid derivatives: celastrol, pristimerin, tingenone, and iguesterin (6) with $\mathrm{IC}_{50}$ values of $10.3,5.5,9.9$, and $2.6 \mu \mathrm{M}$, respectively, against SARS-CoV 3CL ${ }^{\text {pro }}$ (Ryu et al. 2010a).

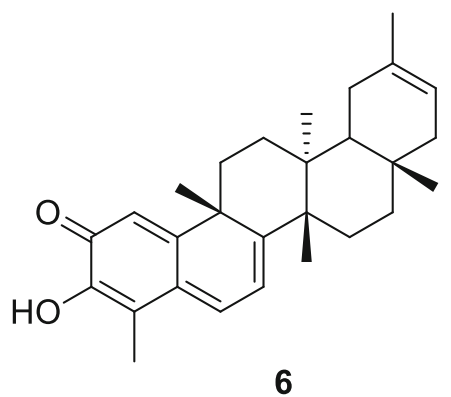

The seeds of Aesculus turbinata Blume, a medicinal plant found in China, Japan, and South Korea, contain a natural saponins called escins, constituents with strong virucidal effects against SARS-CoV $\left(\mathrm{EC}_{50}\right.$ of $6 \mu \mathrm{M}$, selectivity index value of 2.5) (Kim et al. 2017b; Salinas et al. 2019). Betulin and betulinic acid, the main antiviral components of the Betula L. plants, inhibit HIV fusion and one of the steps in HIV maturation (Chinsembu 2016a). A methanolic extract of
Betula papyrifera Marshall exerted antiviral activity against bovine coronavirus (Rastogi et al. 2015).

\section{Polyphenols and Miscellaneous Aromatic Compounds}

Many natural polyphenols, with antioxidant properties, possess antiviral activity and some of them, for example, myricetin (7), an inhibitor of coronavirus helicase $\mathrm{nsP} 13$ ( $\mathrm{IC}_{50}$ value of $2.71 \mu \mathrm{M})$, are already being used against coronaviruses (Semwal et al. 2016; Yu et al. 2012). Naturally occurring flavonoids such as quercetin, naringin, hesperetin, and catechin, the most abundant polyphenols in the human diet, are usually found in fruit and vegetables as glycosides and sometimes as acylglycosides. Luteolin and quercetin can interfere with adsorption of the virus to its host cells. It was hypothesized that specific flavonoids, such as quercetin, hesperetin, and myricetin (7) and their glycosylated derivatives, may play an effective role in inhibiting SARS-CoV entry into host cells, specifically by binding with high affinity to the spike protein, helicase, and protease sites on the ACE receptor (Ngwa et al. 2020), in addition to acting against fatty acid synthase (Wen et al., 2011). Extracted from TCM herbal formulae used to treat SARS, the following active polyphenols inhibited various steps during SARS-CoV entry and replication: baicalin, emodin, epigallocatechin, gallate, gallocatechin gallate, herbacetin, isobavaschalcone, kaempferol derivatives, luteolin, myricetin, quercetin, $3-\beta$-D-glucoside, rhoifolin, pectolinarin, scutellarein, and tetra- $O$-galloyl- $\beta$-D-glucose (Yang et al. 2020).<smiles>[R]c1cc(-c2oc3cc(O)cc(O)c3c(=O)c2O)cc(O)c1O</smiles>

$$
\begin{aligned}
& 7 \mathrm{R}=\mathrm{OH} \\
& 8 \mathrm{R}=\mathrm{H}
\end{aligned}
$$

Quercetin (8) is an aglycone present at high concentration in onions. This compound has virucidal activity against enveloped viruses such as mengovirus, herpes simplex, parainfluenza type 3 , pseudorabies, respiratory syncytial, and Sindbis viruses (Choi et al. 2009). Quercetin is able to inhibit $\mathrm{H}^{+}$-ATPase of lysosomal membrane and thus prevents virus coat removal and blocks viral replication and competitively inhibits SARS-CoV $3 \mathrm{CL}^{\text {pro }}$ with $\mathrm{IC}_{50}$ of $42.79 \pm 4.97 \mu \mathrm{M}$ (Chen et al. 2006).

Torreya nucifera (L.) Siebold \& Zucc. is a traditional medicinal plant in Asia. The ethanol leaf extract of T. nucifera exerts good SARS-CoV 3CL ${ }^{\text {pro }}$ inhibitory activity (62\% at $100 \mu \mathrm{g} / \mathrm{ml}$ ) (Ryu et al. 2010b). Following the bioactivityguided fractionation of $T$. nucifera, the biflavone amentoflavone (9) showed the most potent SARS-CoV 
$3 \mathrm{CL}^{\text {pro }}$ inhibitory effect with $\mathrm{IC}_{50}$ of $8.3 \mu \mathrm{M}$ (Ryu et al. 2010b). Apigenin, luteolin, and quercetin inhibited SARS$\mathrm{CoV} 3 \mathrm{CL}^{\text {pro }}$ activity with $\mathrm{IC}_{50}$ values of $280.8,20.2$, and $23.8 \mu \mathrm{M}$, respectively (Ryu et al. 2010b).<smiles>O=c1cc(-c2ccc(O)c(-c3c(O)cc(O)c4c(=O)cc(-c5ccc(O)cc5)oc34)c2)oc2cc(O)cc(O)c12</smiles>

9

Zhong et al. (2013) found that Jinchai, a capsule of TCM consisting of plants such as Lonicera japonica Thunb., Bupleurum chinense DC., Astragalus membranaceus (Fisch.) Bunge, and Codonopsis pilosula subsp. tangshen (Oliv.) D.Y.Hong inhibited SARS-CoV. Jinchai blocks SARS-CoV infection by weakening adsorption of viruses to cells and reduces the ability of SARS-CoV to infect surrounding tissues (Zhong et al. 2013). The main active constituents of Jinchai are chlorogenic acid and baicalin (10) whose $\mathrm{EC}_{50}(\mu \mathrm{g} / \mathrm{ml})$ at $48 \mathrm{~h}$ was 12.5 to $25, \mathrm{EC}_{50}(\mu \mathrm{g} / \mathrm{ml})$ at $72 \mathrm{~h}$ was 25 to $50, \mathrm{CC}_{50}(\mu \mathrm{g} / \mathrm{ml})$ was $>100$, and SI calculated as $\mathrm{CC}_{50} / \mathrm{EC}_{50}$ at $48 \mathrm{~h}$ was $>4$ to 8 (Chen et al. 2004). Camellia sinensis (L.) Kuntze (black tea) polyphenol epigallocatechin gallate (EGCG) inhibited bovine coronavirus propagation; EGCG interfered with the adsorption of bovine coronavirus to Madin-Darby bovine kidney cells (Bansal et al. 2013). Although Sanguisorba officinalis L. extract inhibits HIV-1 infection by binding to the viral envelope and blocking entry of the virus, it did not inhibit SARS-CoV entry (Liang et al. 2013).<smiles>O=c1cc(-c2ccccc2)oc2cc(OC3OC(CO)[C@@H](O)[C@H](O)[C@H]3O)c(O)c(O)c12</smiles>

10

In oriental herbal medicine, the bark of cinnamon plant Cinnamomum cassia (L.) J. Presl has been used as a spice, infusion, and prime component of herbal remedies for common cold, gastrointestinal infections, cancer, chronic cardiovascular disease, and gynecological disorders. Zhuang et al. (2009) found that cinnamon bark extract has anti-RNA viral effects. The cinnamon extract inhibited wild-type SARS-CoV infection in vitro with an $\mathrm{IC}_{50}$ of $43 \mu \mathrm{M}$; and the proposed mechanism of action for cinnamon bark extract was blocking cell entry via endocytosis (Polansky and Lori 2020). Whereas the antiviral, anti-bacterial, and anti-cancer effects were attributable to essential oils such as cinnamaldehyde (11), the anti-inflammatory actions of cinnamon water extract were due to the presence of polyphenols such as flavonoids and tannins. Molecular docking studies show that 11 may block the attachment of SARC-CoV-2, though detailed in vitro and in vivo studies are required to confirm its efficacy (Asif et al. 2020). Compound $\mathbf{1 1}$ had the lowest electronegativity value among the phytochemicals with a score of -4.34 ; binding affinity in kilocalorie per mole was - 5 (Asif et al. 2020; Kulkarni et al. 2020).<smiles>O=C/C=C/c1ccccc1</smiles>

11

Stilbene derivatives displayed antiviral activities against SARS-CoV (Li et al. 2006). The stilbenoid resveratrol (12) exists widely in different plants including grape Vitis vinifera L., Polygonum cuspidatum, and cranberry Vaccinium macrocarpon Aiton (Lin et al. 2017). Resveratrol inhibits various viral infections, including the inhibition of HIV and SARS-CoV replication (Li et al. 2006). Compound 12 was a potent in vitro inhibitor of SARS-CoV (at $\leq 0.5 \mathrm{mg} / \mathrm{ml}$ ) and MERS-CoV, at $\leq 62.5 \mu \mathrm{M}$ within $24 \mathrm{~h}$ of infection (Li et al. 2006; Lin et al. 2017). It was predicted that resveratrol (12) could be a potential agent against new HCoVs in the near future (Lin et al. 2017).<smiles>Oc1ccc(/C=C/c2cc(O)cc(O)c2)cc1</smiles>

\section{General Inhibitors of Replication}

Polysaccharides isolated from TCM herb Astragalus mongholicus Bunge have been widely used to boost immunity against viruses. A study by Zhang et al. (2018) showed that supplementation with $A$. mongholicus polysaccharides can inhibit the replication of avian coronaviruses. Extracts of Acanthopanax gracilistylus var. trifoliolatus C.B. Shang, the root of Sophora flavescens Aiton, and the dried root of Sanguisorba officinalis and Torilis elata Spreng. reduced the in vitro replication of SARS-CoV more potently than the ribavirin drug control (Kim et al. 2010).

Cimicifuga racemosa (L.) Nutt., Melia azedarach L., Coptis chinensis Franch., Phellodendron chinense C.K.Schneid., and 
Sophora tonkinensis var. polyphylla X.C.Huang \& Z.C.Zhou decreased mouse hepatitis virus A59 (MHV-A59) production and intracellular viral RNA and protein expression with $\mathrm{EC}_{50}$ values ranging from 2 to $27.5 \mu \mathrm{g} / \mathrm{ml}$ ( $\mathrm{Kim}$ et al. 2008). Cimicifuga racemosa, M. azedarach, C. chinensis, $P$. chinense, and $S$. tonkinensis were good candidates for the treatment of coronaviral infections in both humans and animals (Kim et al. 2008). The underlying antiviral mechanism was most likely due to the inhibition of RNA-dependent RNA polymerase or proteases that are crucial for coronavirus RNA replication. Melia azedarach and $C$. chinensis may also affect virus assembly or release.

Silvestrol (13), a natural cyclopenta[b]benzofuran, isolated from the fruits and twigs of Aglaia foveolata Pannell, at 0.6$2 \mu \mathrm{M}$, inhibited cap-dependent viral mRNA translation of HCoV-229E with an $\mathrm{IC}_{50}$ of $40 \mathrm{nM}$ (Müller et al. 2018).

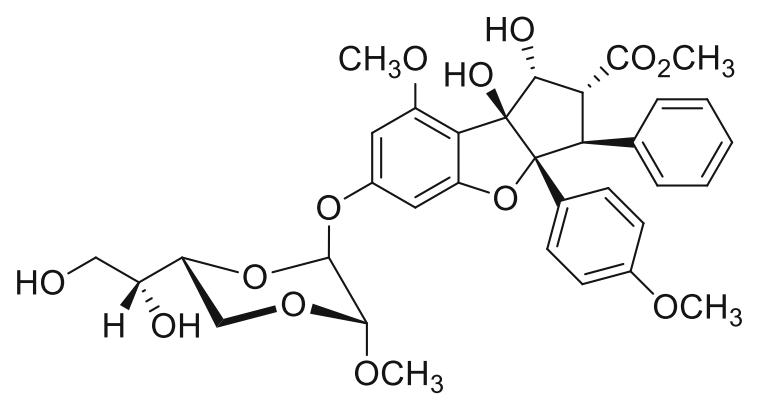

13

Ouabain (14), also known as g-strophanthin, is a toxic cardiac glycoside that was traditionally used as an arrow poison for both hunting and warfare in eastern Africa. However, this substance, in lower doses, can be used medically to treat hypotension and some arrhythmias. In addition, ouabain diminishes SARS-CoV titers and the number of SARS-CoV RNA copies at 0-3000 nM (Yang et al. 2018). Wu et al. (2020) described drug names, chemical structures, pharmacological functions, and sources of 20 potential $\mathrm{RdRp}$ inhibitors from an in-house natural product database. Their results were based on computer virtual screening because no in vitro and in vivo experiments were conducted.<smiles>CC1=C(O)C(=O)C=C2C1=CC=C1[C@@]3(C)CC[C@]4(C)CC[C@](C)(C(=O)O)CC4[C@@]3(C)CC[C@@]21C</smiles>

14

Andrographolide has been studied for its effects on cell signaling, immunomodulation, and stroke. Using computational approaches, Enmozhi et al. (2020) showed that andrographolide (15), an extremelly bitter labdane diterpenoid isolated from Andrographis paniculata (Burm.f.) Wall. ex Nees, docked successfully in the binding site of SARS-CoV-2 $\mathrm{M}^{\text {pro }}$. The molecule obeys Lipinski's rule making it a promising compound to treat COVID-19 (Enmozhi et al. 2020).

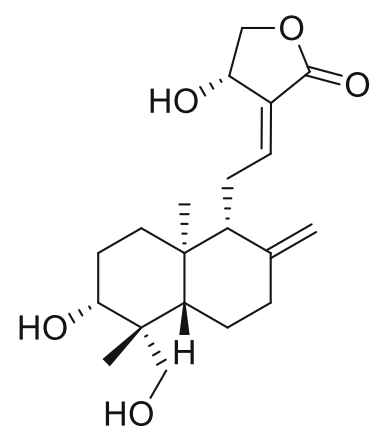

15

Omacetaxine mepesuccinate (trade names Synribo), formerly named as homoharringtonine (16), is a plant alkaloid derived from Cephalotaxus fortunei Hook that was approved by the US FDA in October 2012 for the treatment of chronic myeloid leukemia in adults. Homoharringtonine has been reported to exhibit potent inhibitory activity against coronaviruses, namely porcine epidemic diarrhea virus, murine hepatitis virus (Dong et al. 2018; Andersen et al. 2019), and SARS-CoV-2 with $\mathrm{EC}_{50}$ at $2.10 \mu \mathrm{M}$ (Choy et al. 2020).<smiles>COC(=O)[C@@](O)(CCCCC(C)(C)O)C(=O)O[C@H]1N2CCC3=C(OC)CC[C@@]31c1cc3c(cc1CC2)OCO3</smiles>

16

Tylophorine (17), a phenanthraindolizidine alkaloid, has anti-HCoV activity in the nanomolar concentrations, up to $1000 \mathrm{nM}$ (Islam et al. 2020). Tylophorine derivatives, including naturally occurring and synthetic phenanthroindolizidines and phenanthroquinolizidines, have been identified as potent in vitro inhibitors of enteropathogenic coronavirus transmissible gastroenteritis virus (TGEV). This class of potent compounds showed $\mathrm{EC}_{50}$ values ranging from 8 to $1468 \mathrm{nM}$ as determined by immunofluorescent assay of the expression of TGEV spike and nucleocapsid proteins and by real-time qRTPCR analysis of viral yields. Tylophorine compounds could be novel leads for further drug development on their own or as templates for drug design (Islam et al. 2020). Tylophorine and related alkaloids, isolated from Tylophora indica Merr., inhibit TGEV replication for anti-coronavirus activity and suppress nitric oxide production in RAW264.7 cells, a measure of antiinflammation (Lee et al., 2012a, b). Additionally, a pharmacokinetic study demonstrated high and comparable oral 
bioavailabilities of tylophorine $(65.7 \%)$ in rats (Lee et al., 2012a, b).<smiles>COc1ccc2c3c(c4ccc(OC)c(OC)c4c2c1OC)CN1CCC[C@H]1C3</smiles>

17

\section{Inhibitors of Chymotrypsin-Like Protease in SARS-CoV}

The chymotrypsin-like protease $\left(3 \mathrm{CL}^{\mathrm{pro}}\right)$ is vital for SARs-CoV replication and is therefore a promising drug target. The active site of SARS-CoV $3 \mathrm{CL}^{\text {pro }}$ has a catalytic dyad with the sulfur of Cys145 as a nucleophile and the imidazole ring of His41 as a general base (Ryu et al. 2010a). Also called main protease $\left(\mathrm{M}^{\text {pro }}\right)$, the $3 \mathrm{CL}^{\text {pro }}$ of SARS-CoV mediates the proteolytic processing of replicase polypeptides $1 \mathrm{a}$ and $1 \mathrm{ab}$ into functional proteins; thus, it is an important target for drug development (Lin et al. 2005). Curcumin inhibits SARS-CoV $3 \mathrm{CL}^{\text {pro }}\left(\mathrm{IC}_{50}\right.$ value of $23.5 \mu \mathrm{M}$ ) (Ryu et al. 2010a). The extracts of Cibotium barometz (L.) J.Sm. and Dioscorea batatas Decne. also inhibited SARS-CoV $3 \mathrm{CL}^{\text {pro }}$ activity with $\mathrm{IC}_{50}$ values of $39 \mu \mathrm{g} / \mathrm{ml}$ and $44 \mu \mathrm{g} / \mathrm{ml}$, respectively (Cuong et al. 2009; Wen et al. 2011). Tannic acid, 3-isotheaflavin-3-gallate, and theaflavin-3,3'digallate, three phenolic compounds from black tea, inhibit SARS-CoV $3 \mathrm{CL}^{\text {pro }}$ with $\mathrm{IC}_{50}$ values of 3 , 7 , and $9.5 \mu \mathrm{M}$, respectively (Chen et al. 2005).

Isatis indigotica Fortune root extracts were frequently used as a remedy during the 2002/2003 SARS outbreak in China. A water extract of I. indigotica had anti-SARS-CoV $3 \mathrm{CL}^{\text {pro }}$ activity (Lin et al. 2005). The root extract of I. indigotica contains indigo, indirubin, indican (indoxyl- $\beta$ D-glucoside), $\beta$-sitosterol, $\gamma$-sitosterol, and sinigrin (18). The $\mathrm{IC}_{50}$ in the cell-free assays was $115 \mu \mathrm{M}$ for $\beta$-sitosterol, $121 \mu \mathrm{M}$ for sinigrin, and $300 \mu \mathrm{M}$ for indigo. The cell-based assay indicated that the antioxidant sinigrin $\left(\mathrm{IC}_{50} 217 \mu \mathrm{M}\right)$ was more efficient in blocking the cleavage processing of the $3 \mathrm{CL}^{\text {pro }}$ than indigo $\left(\mathrm{IC}_{50} 752 \mu \mathrm{M}\right)$ and $\beta$-sitosterol $\left(\mathrm{IC}_{50}\right.$ $1210 \mu \mathrm{M})$ (Lin et al. 2005). Compound $\mathbf{1 8}$ is a glucosinolatetype compound also found in some plants of the family Brassicaceae such a Brussels sprouts, broccoli, and the seeds of black mustard (Brassica nigra (L.) Andrz.

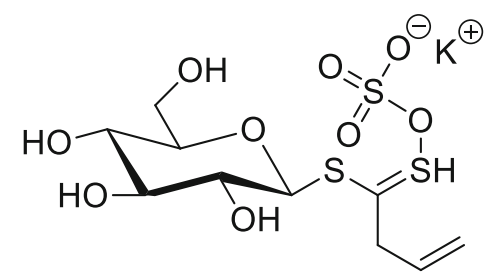

18

\section{Coronavirus Neutralization and Inactivation}

Echinaforce ${ }^{\circledR}$ is a standardized preparation extracted from freshly harvested herb (herba tintura $2580 \mathrm{mg} / 125$ drops) and roots (radix tintura $135 \mathrm{mg} / 125$ drops) of Echinacea purpurea (L.) Moench plants (purple coneflower) with a $65 \%$ alcoholic solution (Schapowal 2020). Echinaforce ${ }^{\circledR}$ reduces the infectivity of HCoV-229E in a dose-dependent manner. It inhibits HCoV-229E infection of respiratory epithelial cells (Schapowal 2020). HCoV-229E was irreversibly inactivated when exposed to Echinaforce ${ }^{\circledR}\left(\mathrm{IC}_{50}\right.$ of $3.2 \mu \mathrm{g} / \mathrm{ml}$ ) (Schapowal 2020). Echinaforce ${ }^{\circledR}$ showed a dosedependent reduction of $\mathrm{HCoV} 229 \mathrm{E}$ infectivity with an $\mathrm{IC}_{50}=$ $9 \pm 3 \mu \mathrm{g} / \mathrm{ml}$ (Engler et al. 2017). Complete neutralization was achieved with $50 \mu \mathrm{g} / \mathrm{ml}$ (Engler et al. 2017).

Similar inhibition was observed for MERS-CoV when $10 \mu \mathrm{g} / \mathrm{ml}$ of Echinaforce ${ }^{\circledR}$ reduced infectivity by $99.9 \%$ and $50 \mu \mathrm{g} / \mathrm{ml}$ of Echinaforce fully blocked infectivity (Engler et al. 2017). Extracts of Echinacea purpurea have been used traditionally in North America for the treatment of various infections and wounds, and they have become very popular herbal medicines globally (Hudson 2012). Rondanelli et al. (2018) found that a combination of E. purpurea, vitamin D, vitamin $\mathrm{C}$, and zinc was useful in the treatment of the common cold. Vitamin D supplementation also lessens the risk of COVID-19 infection and deaths (Grant et al. 2020). Echinacea angustifolia DC., Echinacea pallida (Nutt.) Nutt., and Echinacea purpurea are the most common Echinacea Moench species recognized for treating common cold and SARS (Hudson 2012).

\section{Immunomodulatory Agents}

Coronavirus infection in humans is characterized by uncontrolled replication of the virus and a prominent proinflammatory response (Wong and Yuen 2008). Still, in the management of coronavirus disease, the role of immunomodulators to decrease excessive inflammation remains elusive (Wong and Yuen 2008). The immunomodulatory compounds tomentins A-E (19-23), geranylated flavonoids, isolated from 
Paulownia tomentosa (Thunb.) Steud. lower the concentration of pro-inflammatory cytokines interleukin- $1 \beta$ and tumor necrosis factor alpha (Cho et al. 2013). These tomentins could be useful in allaying the multisystem inflammatory syndrome, also known as the cytokine storm, seen in many COVID-19 patients.<smiles>[R]c1cc(C2Oc3cc4c(c(O)c3C(=O)C2[R4])CCC(C)(CCCC(C)(C)O)O4)cc([R])c1[R]</smiles>

$19 \mathrm{R}_{1}=\mathrm{R}_{2}=\mathrm{OH} ; \mathrm{R}_{3}=\mathrm{R}_{4}=\mathrm{H}$

$20 \mathrm{R}_{1}=\mathrm{OH} ; \mathrm{R}_{2}=\mathrm{OCH}_{3} ; \mathrm{R}_{3}=\mathrm{R}_{4}=\mathrm{H}$

$21 \mathrm{R}_{1}=\mathrm{R}_{2}=\mathrm{OCH}_{3} ; \mathrm{R}_{3}=\mathrm{OH} ; \mathrm{R}_{4}=\mathrm{H}$

$22 \mathrm{R}_{1}=\mathrm{R}_{3}=\mathrm{OCH}_{3} ; \mathrm{R}_{2}=\mathrm{OH} ; \mathrm{R}_{4}=\mathrm{H}$

$23 \mathrm{R}_{1}=\mathrm{OCH}_{3} ; \mathrm{R}_{2}=\mathrm{R}_{4}=\mathrm{OH} ; \mathrm{R}_{3}=\mathrm{H}$

Anti-inflammatory and antineoplastic bisbenzylisoquinoline alkaloids isolated from Stephania tetrandra S.Moore, namely cepharanthine (24), fangchinoline, and tetrandrine, acted as immunomodulators and inhibited the expression of HCoV-OC43 spike and nucleocapsid proteins (Kim et al. 2019). After the cells were infected with $\mathrm{HCoV}-\mathrm{OC} 43$, each compound $(5 \mu \mathrm{M})$ was added to the wells, and cytokine mRNA was qantified by real-time qRT-PCR. Compound treatment following virus infection reduced the mRNA expression levels of IFN- $\alpha 1$ by almost 20 -fold at 4 days post infection, and about 100 -fold reduction for IFN- $\beta 1$ at 3 days post infection (Kim et al. 2019). According to Islam et al. (2020), natural products with anticoronavirus activity are major constituents of common dietary supplements and can therefore be used to improve the immunity of the general population in pandemics such as COVID-19.

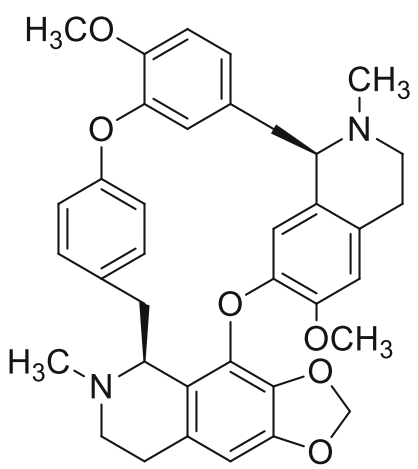

24

\section{Marine Algae and Sponges}

According to Kwon et al. (2013), five phlorotannins of the edible brown algae Ecklonia cava Kjellman competitively inhibit the binding of SARS-CoV spike protein to sialic acids at a concentration of less than $36.6 \mu \mathrm{M}$. Two phlorotannins caused the inhibition of SARS-CoV RNA and SARS-CoV protein synthesis in late stages, with $\mathrm{IC}_{50}$ values of $12.2 \pm 2.8$ and $14.6 \pm 1.3 \mu \mathrm{M}$, respectively (Kwon et al. 2013). The results suggest that compounds isolated from E. cava have strong antiviral activity and may be developed into natural therapeutic drugs against SARS-CoV infection (Kwon et al. 2013). A commercially available E. cava extract, Seapolynol ${ }^{\mathrm{TM}}$, was approved as a new dietary ingredient (NDI) by the US Food and Drug Administration in 2008 (FDA-1995S-0039-0176) (Lee et al., 2012a, b).

An ethanol extract of the edible brown algae Ecklonia cava, Laminariaceae, contained eight phlorotannins that exhibited a dose-dependent (competitive) inhibitory effect on SARS-CoV $3 \mathrm{CL}^{\text {pro }}$ with $\mathrm{IC}_{50}$ values ranging from 2.7 to $164.7 \mu \mathrm{M}$ (Park et al. 2013). Dieckol showed the most potent SARS$\mathrm{CoV} 3 \mathrm{CL}^{\text {pro }}$ trans/cis-cleavage inhibitory effects. Isolated from the marine alga Halimeda tuna (J.Ellis \& Solander) J.V.Lamouroux, halitunal is a novel diterpene aldehyde with a unique cyclopentadieno[c]pyran ring system. Halitunal displayed antiviral activity against murine coronavirus A59 in vitro (Gustafson et al. 2004). Dercitin, an acridine alkaloid isolated from a marine sponge in the genus Dercitus Gray, inhibited the coronavirus $\mathrm{A} 59$ strain $\left(\mathrm{EC}_{50} 1.8 \mu \mathrm{M}\right)$.

Mycalamides $\mathrm{A}$ and $\mathrm{B}$, protein synthesis inhibitors and antiviral compounds isolated from a sponge Mycale incrustans Burton, also inhibited coronavirus A59 (Laport et al. 2009). In vivo activity against coronavirus A59 was observed in mice treated with a $2 \%$ mycalamide mixture at a dosage of $0.2 \mu \mathrm{g} / \mathrm{kg}$ daily with $100 \%$ survival over a 2 -week period (Gallimore 2017). Triterpenes (thyrsiferol, thyrsiferol acetate, venustatriol) isolated from the red alga Laurencia venusta Yamada inhibit coronaviruses, and orthosterol disodium sulfates from the sponge Petrosia weinbergi Van Soest inhibit coronavirus A59 (El Sayed 2000).

Spirulina platensis (Gomont) Geitler is a microscopic filamentous alga rich in proteins, vitamins, essential amino acids, minerals, and essential fatty acids like $\gamma$-linolenic acid. It is produced commercially and sold as a food supplement in health food stores around the world. Spirulina platensis (15 g) enhances the immune status and inflammatory and oxidative markers of COVID-19 patients (McCarty and DiNicolantonio 2020). 


\section{Regional Traditional Medicine and Antiviral Remedies}

\section{China}

Xiao et al. (2003) provided leading insights into the use of fourteen Chinese herbal medicines in the prevention and treatment of SARS. TCM played an important role in the fight against SARS and it was reported by practitioners to be very effective (Lau et al. 2005). The State Administration of TCM of the People's Republic of China formed a panel of TCM specialists to draw up a technical scheme for the prevention and treatment of SARS-CoV using TCM (Chen et al. 2004). Scutellaria baicalensis is one of the most widely used TCMs and its roots are used to treat inflammation, cancer, and viral and bacterial infections. Baicalin, baicalein, wogonin, and oroxylin A are the main active components in S. baicalensis. The most abundant active compound, baicalin, exhibits antiSARS-CoV properties.

Yeh et al. (2013) affirmed that licorice (Glycyrrhiza uralensis Fisch. ex DC.) is a common ingredient in prescriptions of TCM. Licorice has antiviral activity against various DNA and RNA viruses including HIV and SARSCoV. Chinese multi-plant remedy consisting of Houttuynia cordata Thunb., Chrysanthemum morifolium Ramat., Artemisia scoparia Waldst. \& Kit., Eupatorium fortunei Turcz., and Amomum tsao-ko Crevost \& Lemarié was effective in the prevention and treatment of SARSCoV (Zhang and Chen 2008). Extracts of Lonicera japonica are a common TCM used to treat SARS-CoV (Wang et al. 2014). To control SARS-CoV in 2003, L. japonica was widely used in prescriptions publicly published by the State Administration of TCM.

Panax ginseng C.A.Mey., commonly known as ginseng, is a known natural antiviral agent with protective effects against SARS-CoV (Im et al. 2016). Extracts of T. sinensis inhibit SARS-CoV replication (Chen et al. 2008; Wu et al. 2014). Extracts of plants Lycoris radiata Miq., Artemisia annua L., Pyrrosia lingua (Thunb.) Farw., and Lindera aggregata (Sims) Kosterm. displayed anti-SARS-CoV actions with $\mathrm{EC}_{50}$ values of $2.4 \pm 0.2,34.5 \pm 2.6,43.2 \pm 14.1$, and $88.2 \pm$ $7.7 \mu \mathrm{g} / \mathrm{ml}$, respectively (Li et al. 2005). An ethanol stem cortex extract of $L$. radiata was very potent against SARS-CoV ( $\mathrm{EC}_{50}$ of $2.1 \pm 0.2 \mathrm{~nm}$ against the BJ-006 viral strain) (Li et al. 2005). The active compound lycorine was identified as the anti-SARS-CoV component $\left(\mathrm{EC}_{50}\right.$ value of $\left.15.7 \pm 1.2 \mathrm{nM}\right)$. Lycorine shows moderate to potent antiviral activity and reduces viral titers of SARS-CoV (Roy et al. 2018). Jinchai is a widely used TCM that deters SARS-CoV entry, replication, and lung inflammation induced by viral infection (Zhong et al. 2013).

Roots and rhizomes of Glycyrrhiza glabra, a natural sweetener that contains glycyrrhizin, inhibit virus growth and inactivate virus particles. Glycyrrhizic acid, a major triterpene glycoside isolated from Glycyrrhiza species, has activity against several enveloped viruses including SARS-CoV and HIV (Wang et al. 2013). Diammonium glycyrrhizinate, extracted and purified from G. uralensis, inhibited SARS-CoVs (Zhang et al. 2016). Ho et al. (2007) found that two widely used TCM plants in the family Polygonaceae inhibited the interaction of SARSCoV spike protein and ACE2; the $\mathrm{IC}_{50}$ values for extracts of the root tubers of Rheum officinale Baill. and the root tubers/vines of Polygonum multiflorum ranged from 1 to $10 \mu / \mathrm{ml}$ (Ho et al. 2007). Chen et al. (2020) stated that the mortality of COVID-19 patients in China was markedly reduced because of effective combination therapy of TCM and Western medicines. At least 20 patent TCMs were recommended by government guidelines in the treatment of COVID-19 patients in China (Yang et al. 2020). Several TCM plant formulae for treating SARS-CoV and COVID-19 were reported by Yang et al. (2020).

\section{Lebanon}

In Lebanon, the oil of Laurus nobilis Cav. exerted remarkable activity against SARS-CoV with an $\mathrm{IC}_{50}$ value of $120 \mu \mathrm{g} / \mathrm{ml}$ and a selectivity index of 4.16 (Loizzo et al. 2008). An ornamental tree and a member of the Cupressaceae family, Cupressus sempervirens L. contains flavonoid derivatives, diterpenes, catechins and flavonolic oligomers, proanthocyanidins, phenolic acids, fatty acids, and essential oils (Orhan and Tumen 2015). The essential oil of C. sempervirens had a mild inhibitory outcome on SARSCoV activity $(700 \pm 2.3 \mu \mathrm{g} / \mathrm{ml})$ (Orhan and Tumen 2015; Loizzo et al. 2008). Volatile oils are potential agents for treatment of SARS-CoV (Pasdaran et al. 2016). An ethanolic extract of Thymus vulgaris Sm. found in Lebanon inhibits SARS-CoV (Bekut et al. 2018). Lebanese essential oils have also been evaluated for their inhibitory activity against SARS$\mathrm{CoV}$ replication in vitro by visually scoring the virus-induced cytopathogenic effect post infection.

\section{Malaysia}

The papain-like protease $\left(\mathrm{PL}^{\mathrm{pro}}\right.$ ) encoded by SARS-CoV cleaves the viral replicase polyprotein. Since this enzymatic activity is important for viral infection, $\mathrm{PL}^{\text {pro }}$ is a target of interest in the development of antiviral therapies. Nine diarylheptanoids from the bark of Alnus japonica (Thunb.) Steud. were evaluated for their inhibitory activities against SARS-CoV PL ${ }^{\text {pro }}$ (Park et al., 2012a). Hirsutenone was found to be the most potent inhibitor of SARS-CoV PL ${ }^{\text {pro }}\left(\mathrm{IC}_{50}\right.$ of $4.1 \pm 0.3 \mu \mathrm{M})$.

Seven tanshinones isolated from Salvia miltiorrhiza Bunge. were selective inhibitors of SARS-CoV 3CL ${ }^{\text {Pro }}$ and 
$\mathrm{PL}^{\text {Pro }}$ viral cysteine proteases with $\mathrm{IC}_{50}$ values from 0.8 to $30 \mu \mathrm{M}$ (Park et al. 2012b). Cryptotanshinone was the most potent inhibitor of SARS-CoV PL ${ }^{\text {Pro }}$. Cho et al. (2013) obtained 12 flavonoids from the fruits of Paulownia tomentosa that function as SARS-CoV PL ${ }^{\text {Pro }}$ inhibitors. These flavonoids resulted in significant inhibition of SARS-CoV PL ${ }^{\text {pro }}$ in a dose-dependent manner. Tomentin $\mathrm{E}$ exhibited the highest inhibitory effect with an $\mathrm{IC}_{50}$ of $5 \pm 0.06 \mu \mathrm{M}$ (Cho et al. 2013). Tomentin isolated from Sphaeralcea angustifolia (Cav.) G.Don inhibited PL ${ }^{\text {Pro }}$ with $\mathrm{IC}_{50}$ values ranging from 5 to $14.4 \mu \mathrm{M}$.

\section{Singapore}

Chiow et al. (2016) conducted in vitro virus neutralization assays where an ethyl acetate (EA) fraction of Houttuynia cordata and three of its constituent flavonoids were tested on murine coronavirus. With no cytotoxicity, the EA fraction of $H$. cordata, added before the viral adsorption stage, inhibited murine coronavirus $\left(\mathrm{IC}_{50} 0.98 \mu \mathrm{g} / \mathrm{ml}\right.$ ) (Chiow et al. 2016). The flavonoid quercetin weakly inhibited murine coronavirus with a minimum inhibitory concentration of $125 \mu \mathrm{g} / \mathrm{ml}$, cytotoxicity $\mathrm{CC}_{50}$ value of $116.50 \mu \mathrm{g} / \mathrm{ml}$, and selectivity index of 0.93 . The EA fraction and quercetin yielded a long-lasting anti-murine coronavirus effect of up to 6 days. Overall, this study demonstrated that the EA fraction of $H$. cordata and its flavonoid component, quercetin, neutralizes murine coronavirus in vitro (Chiow et al. 2016).

\section{South Africa}

The EPs® 7630 liquid herbal drug Umckaloabo®, a $100 \mu \mathrm{g} / \mathrm{ml}$ extract of Pelargonium sidoides DC., exerts antiinfluenza virus activity in vitro and in vivo (Theisen and Muller 2012). Discovered in South Africa, Umckaloabo, a decoction of the roots of Pelargonium sidoides, was originally used by Zulu traditional healers as a remedy for acute bronchitis. Umckaloabo ${ }^{\circledR}$ is known to inhibit the entry and replication of HCoV-229E (Michaelis et al. 2011). It is a common medication for acute bronchitis in South Africa and Germany.

\section{Clinical Trials}

Although uncontrolled human trials for SARS-CoV anti-infectives have been reported, no randomized controlled trials with a specific anti-coronavirus agent had been conducted with respect to therapy or prophylaxis (Wong and Yuen 2008). There had not been any clinical trials for drugs of infections caused by $\mathrm{HCoV}-\mathrm{OC} 43, \mathrm{HCoV}-229 \mathrm{E}, \mathrm{HCoV}-$ NL63, and HCoV-HKU1 (Wong and Yuen, 2008).

Chen et al. (2004) urged that randomized placebo control trials should assess the efficacy of intravenous baicalin (10) for the treatment of SARS especially in developing countries where such formulations were available and affordable. In a randomized double-blinded placebo controlled trial, quercetin supplementation in doses of 500 and $1000 \mathrm{mg} /$ day for 12 weeks significantly increased plasma quercetin levels with no reported side effects, but neither decreased total number of upper respiratory tract infection sick days nor reduced symptomatology in all subjects (Heinz et al. 2010). Liu et al. (2012) reviewed 12 randomized controlled trials and one quasirandomized controlled trial where 12 herbal remedies were administered on 640 SARS patients.

Case reports, case series, controlled observational studies, and randomized clinical trials provided compelling data that TCM had beneficial effects in the treatment or prevention of SARS (Lau et al. 2005). For example, the rate of fatality in Hong Kong and Singapore was approximately $18 \%$, while the rate for Beijing was initially more than $52 \%$ until the 5 th May 2003 when it decreased to $4 \%$, and then to $1 \%$ after 20th May 2003 (Yang et al. 2020). The dramatic reduction in fatality in Beijing was associated with the use of TCM as a supplement to conventional therapy (Chen and Nakamura 2004). Lau et al. (2005) reported that during the SARS outbreak of 2002/2003, 1063 volunteers including 926 hospital workers and 37 laboratory technicians working in high-risk virus laboratories used TCM, namely Sang Ju Yin plus Yu Ping Feng San. Compared with the $0.4 \%$ of infection in the placebo group, none of the TCM users was infected. In a controlled clinical study, Hsu et al. (2006b) reported that supplementary treatment with TCM resulted in marked relief of symptoms and truncated the disease course. The clinical benefits of TCM were supported by laboratory studies especially for the use of glycyrrhizin (5), baicalin (10), and MOL376, an inhibitor of cathepsin $\mathrm{L}$ that could become a lead compound for SARS therapy (Yang et al. 2020).

After a review of eight randomized controlled trials, Liu et al. (2004) resolved that a combination of TCM with conventional medicine had beneficial effects such as decrease of mortality, relief of symptoms, and control of fungal infections in patients with SARS. However, the trial evidence was not sufficient enough due to the lack of methodological rigour. In a review of 90 peer-reviewed Chinese publications after the SARS epidemic of $2002 / 2003$, Leung (2007) concluded that TCM used together with conventional treatment had positive effects including better control of fever and quicker amelioration of chest infection. Wu et al. (2008) urged a rerun of clinical trials involving TCM for the treatment of SARS because the validity of results was jeopardized by questionable trial designs and experimental biases. TCM should be evaluated in carefully designed clinical trials, either used alone or integrated with Western medicine, to cover the prevention and treatment of patients suffering from COVID-19 pneumonia (Ling 2020). By mid-March 2020, at least 14 TCM clinical trials with a total of 2714 patients were ongoing for the 
treatment of SARS-CoV-2 infection (Yang et al. 2020). Chinese treatment data showed that patented TCM had good therapeutic efficacy in the treatment of COVID-19, with minimal adverse reactions (Zhuang et al. 2020).

\section{Perspective on Future Directions}

Empirical data on SARS-CoV treatments are scarce (Wong and Yuen 2008), and the majority of viral diseases do not have targeted drugs or vaccines (Mahapatra et al. 2019). Although the ongoing SARS-CoV-2 global pandemic should remind scientists that current options for treating life-threatening zoonotic coronavirus infections are very limited (Wu et al. 2020), medicinal plants offer a strong pipeline for the discovery of novel lead compounds that can be converted into new drugs to treat COVID-19. Medicinal plants hold great promise for drug development against SARS-CoV-2, but there is paucity of research on the development of anti-SARS-CoV-2 drugs from natural products. In addition, most of the data on natural products with activity against $\mathrm{HCoVs}$ are from non-clinical and pre-clinical studies (Islam et al. 2020).

Potential anti-coronavirus therapies can be divided into two categories depending on their target: those that act on the human immune system or human cells, and those that interfere with the coronavirus itself (Wu et al. 2020). The unmet need for pharmacologically potent and safe antivirals ought to be fulfilled by thinking out of the box and indigenous knowledge of medicinal plants may be a masterstroke against deadly infectious diseases such as COVID-19 (Mahapatra et al. 2019). Vellingiri et al. (2020) postulated that medicinal plants are potential sources of drugs for the treatment of COVID-19. Ling (2020) also submitted that traditional plant medicines are a good source of natural compounds for the discovery and development of drugs against SARS-CoV-2. So, the mortality of COVID-19 patients in China was limited by the use of TCM. As the growing COVID-19 global pandemic reformats the classical norms of pharmaceutical and clinical interventions, this review is a poignant reminder that repurposing of current medicinal plants and other natural products to treat COVID-19 should become part of our new vernacular health system.

Comparative genomics lends credence to the repurposing of current anti-SARS natural products for the treatment of COVID-19. This is because the genome sequence of SARS$\mathrm{CoV}$ is very similar to that of SARS-CoV-2 (Tahir ul Qamar et al. 2020). Phylogenetic analysis of whole genomes reveals that SARS-CoV-2 shares $79.7 \%$ nucleotide sequence identity with SARS-CoV (Wang et al. 2020a; Zhou et al., 2020a, b). Compared with SARS-CoV, the envelope and nucleocapsid proteins of SARS-CoV-2 share sequence identities of $96 \%$ and $89.6 \%$, respectively (Zhou et al., 2020a, b). The virion of SARS-CoV-2 consists of a similar structure as SARS-CoV and MERS-CoV. Like SARS-CoV, SARS-CoV-2 also uses ACE2 as its cellular receptor to enter host cells (Zhou et al., $2020 \mathrm{a}, \mathrm{b})$. The chymotrypsin-like protease ( $3 \mathrm{CL}^{\text {pro }}$ ) of SARS$\mathrm{CoV}$ is conserved and shares $99.02 \%$ sequence identity with SARS-CoV-2 $3 \mathrm{CL}^{\text {pro }}$ (Tahir ul Qamar et al. 2020). These comparative genomic similarities signify one epic biomedical prospect: if medicinal plants used against SARS-CoV and MERS-CoV are carefully repurposed, they could be effective against SARS-CoV-2. In this new normality, natural products should become part of the COVID-19 survival kit.

In the absence of an effective and safe drug that inhibits SARS-CoV-2, the use of antimalarial plants and synthetic drugs has gained traction in the treatment of COVID-19. The notion that antimalarial plants in the genus Artemisia L. can be repurposed to prevent and treat COVID-19 has often been associated with experimental data that chloroquine inhibits the replication of viruses. Chloroquine inhibits chikungunya virus replication in Vero A cells $\left(\mathrm{IC}_{50} 7 \mu \mathrm{M}\right.$, $\mathrm{IC}_{90} 15 \mu \mathrm{M}$, selectivity index $=37.14$ ) in a dose-dependent manner. Chloroquine, whose chemical structure mimics nucleoside analogues, has in vitro activity against SARS-CoV and SARS-CoV-2 (Wang et al. 2020a). An antimalarial drug known since 1934, chloroquine blocks HIV-1 and HCoVs at a very early stage; it also inhibits the replication of MERS-CoV in a dose-dependent mode $\left(\mathrm{EC}_{50}\right.$ of $3 \mu \mathrm{M}$ ) (de Wilde et al. 2014). Chloroquine exerts antiviral as well as immunomodulatory properties. Chloroquine $\left(\mathrm{EC}_{50}\right.$ of $1.13 \mu \mathrm{M}$ against SARS-CoV-2) blocks viral infection by increasing the endosomal $\mathrm{pH}$ required for viral fusion (Vellingiri et al. 2020). A 9-aminoquinoline, chloroquine inhibits SARS-CoV replication and downregulates IFN- $\gamma$ and TNF- $\alpha$ production in mice (Prinsloo et al. 2018). In the first half of 2020, clinical trials (NCT04261517 and NCT04307693) of hydroxychloroquine treatment for COVID-19 were underway in China (Wang et al. 2020b). The World Health Organization announced it would resume its halted randomized controlled trials to find out whether hydroxychloroquine was able to prevent COVID-19. This was after the Lancet on 4 June 2020, due to concerns with respect to the veracity of the data and analyses, retracted an influential article which had earlier reported that hydroxychloroquine increased the mortality of COVID-19 patients. On 15 June 2020, the US Food and Drug Administration revoked the emergence use of hydroxychloroquine to treat COVID-19 patients after reports that the drug increases the risk of cardiovascular side effects including cardiomyopathy and cardiac arrest.

Taken together, these developments signify that many countries should carefully evaluate the efficacy and safety of natural antimalarial agents for the possible treatment of COVID-19. Rich in flavonoids such as acacetin, genkwanin, and 7-methoxyacacetin, leaf extracts of Artemisia afra Jacq., a common antimalarial remedy in Kenya, Rwanda, and Zambia (Chinsembu 2015), should be carefully evaluated in COVID- 
19 patients. The need for medicinal plants and other natural products to treat COVID-19 patients is urgent especially in Africa where health systems grapple with high caseloads of HIV/AIDS and malaria in addition to being heavily underresourced in terms of funding and staff. Overall, plants with antiplasmodial (Chinsembu 2015), anti-tuberculosis (Chinsembu 2016b), and anti-HIV replication (Chinsembu 2019) activities may present good prospects for the discovery of new active compounds with anti-SARS-CoV-2 action. Pechuel-loeschea leubnitziae O. Hoffm. (Asteraceae), an indigenous plant used to "steam" patients suffering from pneumonia and coughs in Namibia (Kadhila et al. 2020; Mofolo et al. 2020), should also be evaluated for anti-COVID-19 function. High-throughput screening of these plants should be conducted, and computational techniques can quicken the process.

Moreover, plant active compounds should be subjected to absorption, distribution, metabolism, and excretion (ADME) evaluation to verify that oral administration would be effective (Zhang et al. 2020). Analysis of structure-activity relationships may be helpful in understanding the mechanisms of certain active compounds such as myricetin (5), baicalein (6), and quercetin. Further studies including in silico molecular docking simulations should be done to investigate the binding affinities of plant active compounds to SARS-CoV2. A docking analysis can test whether the active compound has the potential to directly interact with SARS-CoV-2 proteins (Zhang et al. 2020). Application of structure-based drug design strategies may aid in the development of novel SARSCoV-2 inhibitors from natural compounds. To predict the general in vivo effects of the natural compounds, network pharmacology analysis can be carried out.

Only $0.0004 \%$ plant samples may directly lead to a commercial drug (Chinsembu 2016a). Thus, there are few plantderived anti-SARS agents in clinical trials. From 2012 to 2017, only twelve new antivirals were approved by the US Food and Drug Administration; eight were for the treatment of pathologies related to hepatitis $\mathrm{C}$ virus and two were combinations of anti-HIV drugs (Mercorelli et al. 2018). Since less than $15 \%$ of plant diversity has been explored for pharmaceutical purposes (Chinsembu, 2016a), the transition from natural product to anti-SARS-CoV-2 drug prototypes is a daunting reality as much as it is a beautiful prospect.

This review shows that plants, fungi, and marine organisms have anti-SARS-CoV properties. Many of these plants, fungi, and marine organisms have other pharmacological benefits because structural diversity and adaptation to various environmental conditions induce them to synthesize defensive compounds with assorted biological activities (Prinsloo et al. 2018). Corollary, diverse plant secondary metabolites are an important library of novel lead compounds that may be functional against SARS-CoV-2. Bio-assay-guided fractionation of medicinal plant extracts may provide a quicker pipeline for the discovery of novel compounds against SARSCoV-2.

An examination of the research publications on anti-SARS natural products cited in this review shows that about 8 out of 10 are authored by the Chinese. Since the Chinese represent about $80 \%$ of all research efforts and publications on antiSARS natural products, there is $80 \%$ chance that the next big discovery of novel natural products to treat COVID-19 will be from TCM. China is the world leader in research and development for innovative anti-SARS agents from natural products. By all intents and purposes, the first wellresearched and clinically proven herbal remedy for COVID19 will most likely be discovered and developed in China.

The most notable gap identified in the current literature is that many countries in Africa, Asia (except China), Australia/ Oceania, Europe, North America, and South America lag behind in terms of research efforts on anti-coronavirus remedies from medicinal plants and other natural products. In many countries all over the world, there is need to conduct detailed ethnobotanical studies to establish putative anti-SARS-CoV-2 medicinal plants and their active compounds. The search for new anti-SARS-CoV-2 agents should be rigorously extended to marine organisms. This review shows that there is a dearth of experimental data on posology and cytotoxicity of plant extracts and active compounds with in vitro activity against SARS-CoV-2. More studies on pan-assay interference compounds (PAINS) and SARS-CoV-2 immunomodulatory agents from plants and other natural products should be conducted. There is also lack of pharmacological and rigorous human clinical trial data in relation to natural products for treating COVID-19.

\section{Conclusions}

The world is in the middle of a COVID-19 pandemic. Although the deadly threat posed by the current COVID-19 pandemic requires the development of new therapeutic agents, there are currently no efficacious and safe vaccines or drugs to prevent or treat this highly infectious disease. Even in developed nations, blockbuster vaccines or drugs have not yet been developed or approved for the prevention and treatment of COVID-19. Only one synthetic drug (remdesivir) has been approved for emergency use in the USA. Compared with placebo, remdesivir did not significantly reduce the mortality of COVID-19 patients in clinical trials. Against this backdrop, this review provides a modest but insightful snapshot of medicinal plants, fungi, and marine organisms that contain putative active compounds that inhibit SARS-CoV-2. 
Data in this review show two recurring motifs. The first one is that the search for herbal remedies against COVID-19 is more intense in China than in any other part of the world. The second is that most putative antiSARS-CoV-2 remedies contain active compounds that inhibit HCoVs at the cellular and molecular levels. Since structure dictates function, many of these compounds inhibit SARS-CoV replication because their chemical structures mimic nucleoside analogues. While many of the natural products possess anti-SARS-CoV properties, their extracts and active compounds should be evaluated for human cytotoxicity and dosage. Putative anti-SARS-CoV-2 extracts and active compounds should be rigorously tested in animal and randomized placebo clinical trials.

Due to the current lack of effective and safe drugs, natural products presented in this review may form part of the health beliefs, self-medication choices, and selfefficacy practices that people may use to manage COVID-19. Natural products presented in this paper form a repertoire of promising leads that may be repurposed into novel drugs, nutraceuticals, and supplements for COVID-19. If there is a long-term remedy for COVID-19, it must lie in Mother Nature's pharmacy of SARS-CoV-2 inhibitors and immunomodulators from plants, fungi, and marine organisms.

Acknowledgments The author is grateful to the anonymous reviewers and to Professor Rogelio Pereda-Miranda, Editor-inChief of Revista Brasileira de Farmacognosia, for their help in improving the original manuscript.

Code Availability Not applicable

Author's Contributions Kazhila C. Chinsembu (Full Professor, University of Namibia) designed the review, did the literature search, and wrote the paper.

Data Availability All data submitted incl. supplementary material.

\section{Compliance with Ethical Standards}

Protection of Human and Animal Subjects The author declares that no experiments were performed on humans or animals for this study.

Confidentiality of Data The author declares that no patient data appear in this article.

Right to Privacy and Informed Consent The author declares that no patient data appear in this article.

Conflict of Interest The author declares that there is no conflict of interest.

\section{References}

Andersen PI, Ianevski A, Lysvand H, Vitkauskiene A, Oksenych V, Bjørås M, Telling K, Lutsar I, Dampis U, Irie Y, Tenson T (2020) Discovery and development of safe-in-man broad-spectrum antiviral agents. Int J Infect Dis 93:268-276. https://doi.org/10.1016/j.ijid. 2020.02.018

Andersen PI, Krpina K, Ianevski A, Shtaida N, Jo E, Yang J, Koit S, Tenson T, Hukkanen V, Anthonsen MW, Bjoras M (2019) Novel antiviral activities of obatoclax, emetine, niclosamide, brequinar, and homoharringtonine. Viruses 11:964. https://doi.org/10.3390/ v11100964

Asif M, Saleem M, Saadullah M, Yaseen HS, Al Zarzour R (2020) COVID-19 and therapy with essential oils having antiviral, antiinflammatory, and immunomodulatory properties. Inflammopharmacology. https://doi.org/10.1007/s10787-02000744-0

Baltina LA, Zarubaev VV, Baltina LA, Orshanskaya IA, Fairushina AI, Kiselev OI, Yunusov MS (2015) Glycyrrhizic acid derivatives as influenza A/H1N1 virus inhibitors. Bioorg Med Chem Lett 25: 1742-1746. https://doi.org/10.1016/j.bmcl.2015.02.074

Bansal S, Choudhary S, Sharma M, Kumar SS, Lohan S, Bhardwaj V, Syan N, Jyoti S (2013) Tea: a native source of antimicrobial agents. Food Res Int 53:568-584. https://doi.org/10.1016/j.foodres.2013. 01.032

Bekut M, Brkić S, Kladar N, Dragović G, Gavarić N, Božin B (2018) Potential of selected Lamiaceae plants in anti (retro) viral therapy. Pharmacol Res 133:301-314. https://doi.org/10.1016/j.phrs.2017. 12.016

Chang FR, Yen CT, Ei-Shazly M, Lin WH, Yen MH, Lin KH, Wu YC (2012) Anti-human coronavirus (anti-HCoV) triterpenoids from the leaves of Euphorbia neriifolia. Nat Prod Commun 7: 1934578X1200701. https://doi.org/10.1177/1934578X1200701103

Chen CJ, Michaelis M, Hsu HK, Tsai CC, Yang KD, Wu YC, Cinatl J Jr, Doerr HW (2008) Toona sinensis Roem tender leaf extract inhibits SARS coronavirus replication. J Ethnopharmacol 120:108-111. https://doi.org/10.1016/j.jep.2008.07.048

Chen CN, Lin CPC, Huang KK, Chen WC, Hsieh HP, Liang PH, Hsu JTA (2005) Inhibition of SARS-CoV 3C-like protease activity by theaflavin-3,3'-digallate (TF3). Evid Based Complement Alternat Med 2:209-215. https://doi.org/10.1093/ecam/neh081

Chen F, Chan KH, Jiang Y, Kao RY, Lu HT, Fan KW, Cheng VC, Tsui WH, Hung IF, Lee TS, Guan Y (2004) In vitro susceptibility of 10 clinical isolates of SARS coronavirus to selected antiviral compounds. J Clin Virol 31:69-75. https://doi.org/10.1016/j.jcv.2004. 03.003

Chen L, Li J, Luo C, Liu H, Xu W, Chen G, Liew OW, Zhu W, Puah CM, Shen X, Jiang H (2006) Binding interaction of quercetin-3- $\beta$ galactoside and its synthetic derivatives with SARS-CoV $3 \mathrm{CL}^{\text {pro }}$ : structure-activity relationship studies reveal salient pharmacophore features. Bioorg Med Chem 14:8295-8306. https://doi.org/10.1016/ j.bmc.2006.09.014

Chen Q, Quan B, Li X, Gao G, Zheng W, Zhang J, Zhang Z, Liu C, Li L, Wang C, Zhang G (2020) A report of clinical diagnosis and treatment of nine cases of coronavirus disease 2019. J Med Virol 92: 683-687. https://doi.org/10.1002/jmv.25755

Chen Z, Nakamura T (2004) Statistical evidence for the usefulness of Chinese medicine in the treatment of SARS. Phytother Res 18: 592-594. https://doi.org/10.1002/ptr.1485

Cheng PW, Ng LT, Chiang LC, Lin CC (2006) Antiviral effects of saikosaponins on human coronavirus 229E in vitro. Clin Exp Pharmacol Physiol 33:612-616. https://doi.org/10.1111/j.14401681.2006.04415.x 
Chinsembu KC (2015) Plants as antimalarial agents in Sub-Saharan Africa. Acta Trop 152:32-48. https://doi.org/10.1016/j.actatropica. 2015.08.009

Chinsembu KC (2016a) Green Medicines: pharmacy of natural products for HIV and five AIDS-related infections. Africa in Canada Press, Toronto

Chinsembu KC (2016b) Tuberculosis and nature's pharmacy of putative anti-tuberculosis agents. Acta Trop 153:46-56. https://doi.org/10. 1016/j.actatropica.2015.10.004

Chinsembu KC (2019) Chemical diversity and activity profiles of HIV-1 reverse transcriptase inhibitors from plants. Rev Bras 29:504-528. https://doi.org/10.1016/j.bjp.2018.10.006

Chiow KH, Phoon MC, Putti T, Tan BK, Chow VT (2016) Evaluation of antiviral activities of Houttuynia cordata Thunb. extract, quercetin, quercetrin and cinanserin on murine coronavirus and dengue virus infection. Asian Pac J Trop Med 9. https://doi.org/10.1016/j.apjtm. 2015.12.002

Cho JK, Curtis-Long MJ, Lee KH, Kim DW, Ryu HW, Yuk HJ, Park KH (2013) Geranylated flavonoids displaying SARS-CoV papain-like protease inhibition from the fruits of Paulownia tomentosa. Bioorg Med Chem 21:3051-3057. https://doi.org/10.1016/j.bmc.2013.03. 027

Choi HJ, Kim JH, Lee CH, Ahn YJ, Song JH, Baek SH, Kwon DH (2009) Antiviral activity of quercetin 7-rhamnoside against porcine epidemic diarrhea virus. Antivir Res 81:77-81. https://doi.org/10. 1016/j.antiviral.2008.10.002

Choy KT, Wong AY, Kaewpreedee P, Sia SF, Chen D, Hui KP, Chu DK, Chan MC, Cheung PP, Huang X, Peiris M (2020) Remdesivir, lopinavir, emetine, and homoharringtonine inhibit SARS-CoV-2 replication in vitro. Antivir Res 178:104786. https://doi.org/10. 1016/j.antiviral.2020.104786

Cinatl J, Morgenstern B, Bauer G, Chandra P, Rabenau H, Doerr HW (2003) Glycyrrhizin, an active component of liquorice roots, and replication of SARS-associated coronavirus. Lancet 361:20452046. https://doi.org/10.1016/s0140-6736(03)13615-x

Cuong NX, Minh CV, Kiem PV, Huong HT, Ban NK, Nhiem NX, Tung NH, Jung JW, Kim HJ, Kim SY, Kim JA (2009) Inhibitors of osteoclast formation from rhizomes of Cibotium barometz. J Nat Prod 72:1673-1677. https://doi.org/10.1021/np9004097

De Clercq E (2005) Recent highlights in the development of new antiviral drugs. Curr Opin Microbiol 8:552-560. https://doi.org/10.1016/j. mib.2005.08.010

de Wilde AH, Jochmans D, Posthuma CC, Zevenhoven-Dobbe JC, Van Nieuwkoop S, Bestebroer TM, Van Den Hoogen BG, Neyts J, Snijder EJ (2014) Screening of an FDA-approved compound library identifies four small-molecule inhibitors of Middle East respiratory syndrome coronavirus replication in cell culture. Antimicrob Agents Chemother 58:4875-4884. https://doi.org/10.1128/AAC.03011-14

Dong HJ, Wang ZH, Meng W, Li CC, Hu YX, Zhou L, Wang XJ (2018) The natural compound homoharringtonine presents broad antiviral activity in vitro and in vivo. Viruses 10:601. https://doi.org/10.3390/ v10110601

Dong X, Fu J, Yin X, Cao S, Li X, Lin L, Huyiligeqi NJ (2016) Emodin: a review of its pharmacology, toxicity and pharmacokinetics. Phytother Res 30:1207-1218. https://doi.org/10.1002/ptr.5631

El Sayed KA (2000) Natural products as antiviral agents. Stud Nat Prod Chem 24:473-572. https://doi.org/10.1016/S1572-5995(00)800514

Elfiky AA (2020) Anti-HCV, nucleotide inhibitors, repurposing against COVID-19. Life Sci 248:117477. https://doi.org/10.1016/j.lfs.2020. 117477

Engler O, Strasser M, Signer J, Schoop R (2017) Neutralizing activity of Echinacea purpurea on coronaviruses including highly pathogenic Middle-East-Respiratory Syndrome Virus (MERS-CoV). Planta Med Int Open 4:S1-S202. https://doi.org/10.1055/s-0037-1608557
Enmozhi SK, Raja K, Sebastine I, Joseph J (2020) Andrographolide as a potential inhibitor of SARS-CoV-2 main protease: an in silico approach. J Biomol Struct Dyn:1-7. https://doi.org/10.1080/ 07391102.2020 .1760136

Ford N, Vitoria M, Rangaraj A, Norris SL, Calmy A, Doherty M (2020) Systematic review of the efficacy and safety of antiretroviral drugs against SARS, MERS, or COVID-19: initial assessment. J Int AIDS Soc 23:e25489. https://doi.org/10.1002/jia2.25489

Forni D, Cagliani R, Clerici M, Sironi M (2017) Molecular evolution of human coronavirus genomes. Trends Microbiol 25:35-48. https:// doi.org/10.1016/j.tim.2016.09.001

Gallimore W (2017) Marine metabolites: oceans of opportunity. Pharmacognosy, Academic Press, pp. 377-400. https://doi.org/10. 1016/B978-0-12-802104-0.00018-4

Grant WB, Lahore H, McDonnell SL, Baggerly CA, French CB, Aliano JL, Bhattoa HP (2020) Evidence that vitamin D supplementation could reduce risk of influenza and COVID-19 infections and deaths. Nutrients 12:988. https://doi.org/10.3390/nu12040988

Gustafson KR, Oku N, Milanowski DJ (2004) Antiviral marine natural products. Curr Med Chem: Anti-Infect Agents 3:233-249. https:// doi.org/10.2174/15680120433539

Heinz SA, Henson DA, Austin MD, Jin F, Nieman DC (2010) Quercetin supplementation and upper respiratory tract infection: a randomized community clinical trial. Pharmacol Res 62:237-242. https://doi. org/10.1016/j.phrs.2010.05.001

Ho TY, Wu SL, Chen JC, Li CC, Hsiang CY (2007) Emodin blocks the SARS coronavirus spike protein and angiotensin-converting enzyme 2 interaction. Antivir Res 74:92-101. https://doi.org/10. 1016/j.antiviral.2006.04.014

Hsieh PW, Chang FR, Chang CH, Cheng PW, Chiang LC, Zeng FL, Lin $\mathrm{KH}, \mathrm{Wu}$ YC (2004) 2-Substituted benzoxazinone analogues as antihuman coronavirus (anti-HCoV) and ICAM-1 expression inhibition agents. Bioorg Med Chem Lett 14:4751-4754. https://doi.org/10. 1016/j.bmcl.2004.06.083

Hsu CH, Hwang KC, Chao CL, Chang SG, Ho MS, Chou P (2006a) Can herbal medicine assist against avian flu? Learning from the experience of using supplementary treatment with Chinese medicine on SARS or SARS-like infectious disease in 2003. J Altern Complement Med 12:505-506. https://doi.org/10.1089/acm.2006. 12.505

Hsu CH, Hwang KC, Chao CL, Chang SG, Ker CC, Chien LC, Ho MS, Lin JG, Chen YM, Chou P (2006b) The lesson of supplementary treatment with Chinese medicine on severe laboratory-confirmed SARS patients. Am J Chin Med 34:927-935. https://doi.org/10. 1142/S0192415X06004405

Huang IC, Bosch BJ, Li F, Li W, Lee KH, Ghiran S, Vasilieva N, Dermody TS, Harrison SC, Dormitzer PR, Farzan M (2006) SARS coronavirus, but not human coronavirus NL63, utilizes cathepsin L to infect ACE2-expressing cells. J Biol Chem 281:31983203. https://doi.org/10.1074/jbc.M508381200

Hudson JB (2012) Applications of the phytomedicine Echinacea purpurea (purple coneflower) in infectious diseases. Biomed Res Int 2012:1-16. https://doi.org/10.1155/2012/769896

Hyun SK, Lee H, Kang SS, Chung HY, Choi JS (2009) Inhibitory activities of Cassia tora and its anthraquinone constituents on angiotensin-converting enzyme. Phytother Res 23:178-184. https://doi.org/10.1002/ptr.2579

Im K, Kim J, Min H (2016) Ginseng, the natural effectual antiviral: protective effects of Korean red ginseng against viral infection. J Ginseng Res 40:309-314. https://doi.org/10.1016/j.jgr.2015.09.002

Islam MT, Sarkar C, El-Kersh DM, Jamaddar S, Uddin SJ, Shilpi JA, Mubarak MS (2020) Natural products and their derivatives against coronavirus: a review of the non-clinical and pre-clinical data. Phytother Res 2020:1-22. https://doi.org/10.1002/ptr.6700

Kadhila NP, Sekhoacha M, Tselanyane M, Chinsembu KC, MolefeKhamanga DM (2020) Determination of the antiplasmodial activity, 
cytotoxicity and active compound of Pechuel-loeschea leubnitziae O. Hoffm. (Asteraceae) of Namibia. SN Appl Sci 2. https://doi.org/ 10.1007/s42452-020-2926-6

Keum YS, Jeong YJ (2012) Development of chemical inhibitors of the SARS coronavirus: viral helicase as a potential target. Biochem Pharmacol 84:1351-1358. https://doi.org/10.1016/j.bcp.2012.08. 012

Keyaerts E, Vijgen L, Pannecouque C, Van Damme E, Peumans W, Egberink H, Balzarini J, Van Ranst M (2007) Plant lectins are potent inhibitors of coronaviruses by interfering with two targets in the viral replication cycle. Antivir Res 75:179-187. https://doi.org/10.1016/j. antiviral.2007.03.003

Kim DE, Min JS, Jang MS, Lee JY, Shin YS, Park CM, Song JH, Kim HR, Kim S, Jin YH, Kwon S (2019) Natural bis-benzylisoquinoline alkaloids-tetrandrine, fangchinoline, and cepharanthine, inhibit human coronavirus OC43 infection of MRC-5 human lung cells. Biomol 9:696. https://doi.org/10.3390/biom9110696

Kim HY, Eo EY, Park H, Kim YC, Park S, Shin HJ, Kim K (2010) Medicinal herbal extracts of Sophorae radix, Acanthopanacis cortex, Sanguisorbae radix and Torilis fructus inhibit coronavirus replication in vitro. Antivir Ther 15:697-709. https://doi.org/10. 3851/IMP1615

Kim HY, Shin HS, Park H, Kim YC, Yun YG, Park S, Shin HJ, Kim K (2008) In vitro inhibition of coronavirus replications by the traditionally used medicinal herbal extracts, Cimicifuga rhizoma, Meliae cortex, Coptidis rhizoma, and Phellodendron cortex. J Clin Virol 41:122-128. https://doi.org/10.1016/j.jcv.2007.10.011

Kim JW, Cho H, Kim E, Shim SH, Yang JL, Oh WK (2017a) Antiviral escin derivatives from the seeds of Aesculus turbinata Blume (Japanese horse chestnut). Bioorg Med Chem Lett 27:3019-3025. https://doi.org/10.1016/j.bmcl.2017.05.022

Kim KH, Tandi TE, Choi JW, Moon JM, Kim MS (2017b) Middle East respiratory syndrome coronavirus (MERS-CoV) outbreak in South Korea, 2015: epidemiology, characteristics and public health implications. J Hosp Infect 95:207-213. https://doi.org/10.1016/j.jhin. 2016.10.008

Kuba K, Imai Y, Rao S, Gao H, Guo F, Guan B, Huan Y, Yang P, Zhang Y, Deng W, Bao L (2005) A crucial role of angiotensin converting enzyme 2 (ACE2) in SARS coronavirus-induced lung injury. Nat Med 11:875-879. https://doi.org/10.1038/nm1267

Kulkarni SA, Nagarajan SK, Ramesh V, Palaniyandi V, Selvam SP, Madhavan T (2020) Computational evaluation of major components from plant essential oils as potent inhibitors of SARS-CoV-2 spike protein. J Mol Struct 1221:128823. https://doi.org/10.1016/j. molstruc. 2020.128823

Kumaki Y, Wandersee MK, Smith AJ, Zhou Y, Simmons G, Nelson NM, Bailey KW, Vest ZG, Li JK, Chan PK, Smee DF (2011) Inhibition of severe acute respiratory syndrome coronavirus replication in a lethal SARS-CoV BALB/c mouse model by stinging nettle lectin, Urtica dioica agglutinin. Antivir Res 90:22-32. https://doi.org/10. 1016/j.antiviral.2011.02.003

Kwon HJ, Ryu YB, Kim YM, Song N, Kim CY, Rho MC, Jeong JH, Cho KO, Lee WS, Park SJ (2013) In vitro antiviral activity of phlorotannins isolated from Ecklonia cava against porcine epidemic diarrhea coronavirus infection and hemagglutination. Bioorg Med Chem 21:4706-4713. https://doi.org/10.1016/j.bmc.2013.04.085

Laport MS, Santos OCS, Muricy G (2009) Marine sponges: potential sources of new antimicrobial drugs. Curr Pharm Biotechnol 10: 86-105. https://doi.org/10.2174/138920109787048625

Lau TF, Leung PC, Wong EL, Fong C, Cheng KF, Zhang SC, Lam CW, Wong V, Choy KM, Ko WM (2005) Using herbal medicine as a means of prevention experience during the SARS crisis. Am J Chin Med 33:345-356. https://doi.org/10.1142/S0192415X05002965

Lee C (2019) Griffithsin, a highly potent broad-spectrum antiviral lectin from red algae: from discovery to clinical application. Mar Drugs 17:567. https://doi.org/10.3390/md17100567
Lee DH, Park MY, Shim BJ, Youn HJ, Hwang HJ, Shin HC, Jeon HK (2012a) Effects of Ecklonia cava polyphenol in individuals with hypercholesterolemia: a pilot study. J Med Food 15:1038-1044. https://doi.org/10.1089/jmf.2011.1996

Lee YZ, Yang CW, Hsu HY, Qiu YQ, Yeh TK, Chang HY, Chao YS, Lee SJ (2012b) Synthesis and biological evaluation of tylophorinederived dibenzoquinolines as orally active agents: exploration of the role of tylophorine e ring on biological activity. J Med Chem 55: 10363-10377. https://doi.org/10.1021/jm300705j

Leung PC (2007) The efficacy of Chinese medicine for SARS: a review of Chinese publications after the crisis. Am J Chin Med 35:575-581. https://doi.org/10.1142/S0192415X07005077

Li YQ, Li ZL, Zhao WJ, Wen RX, Meng QW, Zeng Y (2006) Synthesis of stilbene derivatives with inhibition of SARS coronavirus replication. Eur J Med Chem 41:1084-1089. https://doi.org/10.1016/j. ejmech.2006.03.024

Li G, Fan Y, Lai Y, Han T, Li Z, Zhou P, Pan P, Wang W, Hu D, Liu X, Zhang Q (2020) Coronavirus infections and immune responses. J Med Virol 92:424-432. https://doi.org/10.1002/jmv.25685

Li SY, Chen C, Zhang HQ, Guo HY, Wang H, Wang L, Zhang X, Hua SN, Yu J, Xiao PG, Li RS (2005) Identification of natural compounds with antiviral activities against SARS-associated coronavirus. Antivir Res 67:18-23. https://doi.org/10.1016/j.antiviral.2005. 02.007

Liang J, Chen J, Tan Z, Peng J, Zheng X, Nishiura K, Ng J, Wang Z, Wang D, Chen Z, Liu L (2013) Extracts of the medicinal herb Sanguisorba officinalis inhibit the entry of human immunodeficiency virus-1. J Food Drug Anal 21:S52-S58. https://doi.org/10.1016/j. jfda.2013.09.034

Lin CW, Tsai FJ, Tsai CH, Lai CC, Wan L, Ho TY, Hsieh CC, Chao PD (2005) Anti-SARS coronavirus 3C-like protease effects of Isatis indigotica root and plant-derived phenolic compounds. Antivir Res 68:36-42. https://doi.org/10.1016/j.antiviral.2005.07.002

Lin SC, Ho CT, Chuo WH, Li S, Wang TT, Lin CC (2017) Effective inhibition of MERS-CoV infection by resveratrol. BMC Infect Dis 17:144. https://doi.org/10.1186/s12879-017-2253-8

Ling CQ (2020) Traditional Chinese medicine is a resource for drug discovery against 2019 novel coronavirus (SARS-CoV-2). J Integr Med 18:87-88. https://doi.org/10.1016/j.joim.2020.02.004

Liu J, Manheimer E, Shi Y, Gluud C (2004) Chinese herbal medicine for severe acute respiratory syndrome: a systematic review and metaanalysis. J Altern Complement Med 10:1041-1051. https://doi.org/ 10.1089/acm.2004.10.1041

Liu X, Zhang M, He L, Li Y (2012) Chinese herbs combined with Western medicine for severe acute respiratory syndrome (SARS). Cochrane Database Syst Rev 10:1465-1858. https://doi.org/10. 1002/14651858.CD004882.pub3

Liu Y, Liu J, Pang X, Liu T, Ning Z, Cheng G (2015) The roles of direct recognition by animal lectins in antiviral immunity and viral pathogenesis. Molecules 20:2272-2295. https://doi.org/10.3390/ molecules 20022272

Loizzo MR, Saab AM, Tundis R, Statti GA, Menichini F, Lampronti I, Gambari R, Cinatl J, Doerr HW (2008) Phytochemical analysis and in vitro antiviral activities of the essential oils of seven Lebanon species. Chem Biodivers 5:461-470. https://doi.org/10.1002/cbdv. 200890045

Lu R, Zhao X, Li J, Niu P, Yang B, Wu H, Wang W, Song H, Huang B, Zhu N, Bi Y (2020) Genomic characterisation and epidemiology of 2019 novel coronavirus: implications for virus origins and receptor binding. Lancet 395:565-574. https://doi.org/10.1016/S01406736(20)30251-8

Mahapatra AD, Bhowmik P, Banerjee A, Das A, Ojha D, Chattopadhyay D (2019) Ethnomedicinal wisdom: an approach for antiviral drug development. In New look to phytomedicine (pp. 35-61), Academic Press. https://doi.org/10.1016/B978-0-12-814619-4.00003-3 
McCarty MF, DiNicolantonio JJ (2020) Nutraceuticals have potential for boosting the type 1 interferon response to RNA viruses including influenza and coronavirus. Prog Cardiovasc Dis 63:383-385. https://doi.org/10.1016/j.pcad.2020.02.007

Mercorelli B, Palù G, Loregian A (2018) Drug repurposing for viral infectious diseases: how far are we? Trends Microbiol 6:865-876. https://doi.org/10.1016/j.tim.2018.04.004

Michaelis M, Doerr HW, Cinatl J Jr (2011) Investigation of the influence of EPs ${ }^{\circledR} 7630$, a herbal drug preparation from Pelargonium sidoides, on replication of a broad panel of respiratory viruses. Phytomedicine 18:384-386. https://doi.org/10.1016/j.phymed. 2010.09.008

Mitchell CA, Ramessar K, O'Keefe BR (2017) Antiviral lectins: selective inhibitors of viral entry. Antivir Res 142:37-54. https://doi.org/10. 1016/j.antiviral.2017.03.007

Mofolo MJ, Kadhila P, Chinsembu KC, Mashele S, Sekhoacha M (2020) Green synthesis of silver nanoparticles from extracts of Pechuelloeschea leubnitziae: their anti-proliferative activity against the U87 cell line. Inorg Nano-Met Chem 50:949-955. https://doi.org/ 10.1080/24701556.2020.1729191

Morigiwa A, Kitabatake K, Fujimoto Y, Ikekawa N (1986) Angiotensin converting enzyme-inhibitory triterpens from Ganoderma lucidum. Chem Pharm Bull 34:3025-3028 https://www.jstage.jst.go.jp/ article/cpb1958/34/7/34_7_3025/_pdf

Müller C, Schulte FW, Lange-Grünweller K, Obermann W, Madhugiri R, Pleschka S, Ziebuhr J, Hartmann RK, Grünweller A (2018) Broad-spectrum antiviral activity of the eIF4A inhibitor silvestrol against corona- and picornaviruses. Antivir Res 150:123-129. https://doi.org/10.1016/j.antiviral.2017.12.010

Ngwa W, Kumar R, Thompson D, Lyerly W, Moore R, Reid TE, Lowe H, Toyang N (2020) Potential of flavonoid-inspired phytomedicines against COVID-19. Molecules 25:2707. https://doi.org/10.3390/ molecules 25112707

Orhan IE, Tumen I (2015) Potential of Cupressus sempervirens (Mediterranean cypress) in health. In The Mediterranean diet (pp. 639-647). Academic Press. https://doi.org/10.1016/B978-0-12407849-9.00057-9

Park JY, Jeong HJ, Kim JH, Kim YM, Park SJ, Kim D, Park KH, Lee WS, Ryu YB (2012a) Diarylheptanoids from Alnus japonica inhibit papain-like protease of severe acute respiratory syndrome coronavirus. Biol Pharm Bull 35:2036-2042. https://doi.org/10.1248/bpb. b12-00623

Park JY, Kim JH, Kim YM, Jeong HJ, Kim DW, Park KH, Kwon HJ, Park SJ, Lee WS, Ryu YB (2012b) Tanshinones as selective and slow-binding inhibitors for SARS-CoV cysteine proteases. Bioorg Med Chem 20:5928-5935. https://doi.org/10.1016/j.bmc.2012.07. 038

Park JY, Kim JH, Kwon JM, Kwon HJ, Jeong HJ, Kim YM, Kim D, Lee WS, Ryu YB (2013) Dieckol, a SARS-CoV 3CL ${ }^{\text {pro }}$ inhibitor, isolated from the edible brown algae Ecklonia cava. Bioorg Med Chem 21:3730-3737. https://doi.org/10.1016/j.bmc.2013.04.026

Pasdaran A, Pasdaran A Sheikhi D (2016) Volatile oils: potential agents for the treatment of respiratory infections. In: Kon K, Rai M (eds) The microbiology of respiratory system infections. Academic Press, pp. 237-261. https://doi.org/10.1016/B978-0-12-804543-5.00016-6

Pillaiyar T, Meenakshisundaram S, Manickam M (2020) Recent discovery and development of inhibitors targeting coronaviruses. Drug Discov Today 25:668-688. https://doi.org/10.1016/j.drudis.2020. 01.015

Polansky H, Lori G (2020) Coronavirus (COVID-19), first indication of efficacy of gene-eden-VIR/novirin in SARS-CoV-2 infections. Int J Antimicrob Agents 55:105971. https://doi.org/10.1016/j. ijantimicag.2020.105971

Prinsloo G, Marokane CK, Street RA (2018) Anti-HIV activity of southern African plants: current developments, phytochemistry and future research. J Ethnopharmacol 210:133-155. https://doi.org/10.1016/j. jep.2017.08.005

Rastogi S, Pandey MM, Rawat AKS (2015) Medicinal plants of the genus Betula - traditional uses and a phytochemical-pharmacological review. J Ethnopharmacol 159:62-83. https://doi.org/10.1016/j.jep. 2014.11.010

Remuzzi A, Remuzzi G (2020) COVID-19 and Italy: what next? Lancet 395:1225-1228. https://doi.org/10.1016/S0140-6736(20)30627-9

Rondanelli M, Miccono A, Lamburghini S, Avanzato I, Riva A, Allegrini P, Faliva MA, Peroni G, Nichetti M, Perna S (2018) Self-care for common colds: the pivotal role of vitamin D, vitamin C, zinc, and Echinacea in three main immune interactive clusters (physical barriers, innate and adaptive immunity) involved during an episode of common colds - practical advice on dosages and on the time to take these nutrients/botanicals in order to prevent or treat common colds. Evid Based Complement Alternat Med. https://doi.org/10.1155/ 2018/5813095

Roy M, Liang L, Xiao X, Feng P, Ye M, Liu J (2018) Lycorine: a prospective natural lead for anticancer drug discovery. Biomed Pharmacother 107:615-624. https://doi.org/10.1016/j.biopha.2018. 07.147

Ryu YB, Jeong HJ, Kim JH, Kim YM, Park JY, Kim D, Naguyen TT, Park SJ, Chang JS, Park KH, Rho MC (2010b) Biflavonoids from Torreya nucifera displaying SARS-CoV 3CL ${ }^{\text {pro }}$ inhibition. Bioorg Med Chem 18:7940-7947. https://doi.org/10.1016/j.bmc.2010.09. 035

Ryu YB, Park SJ, Kim YM, Lee JY, Seo WD, Chang JS, Park KH, Rho MC, Lee WS (2010a) SARS-CoV 3CL ${ }^{\text {pro }}$ inhibitory effects of quinone-methide triterpenes from Tripterygium regelii. Bioorg Med Chem Lett 20:1873-1876. https://doi.org/10.1016/j.bmcl. 2010.01.152

Salinas FM, Vázquez L, Gentilini MV, Regueira E, Jodar MS, Viegas M, Michelini FM, Hermida G, Alché LE, Bueno CA (2019) Aesculus hippocastanum L. seed extract shows virucidal and antiviral activities against respiratory syncytial virus (RSV) and reduces lung inflammation in vivo. Antivir Res 164:1-11. https://doi.org/10.1016/j. antiviral.2019.01.018

Schapowal DA (2020) Use of Echinaforce to prevent coronavirus infections. EC Microbiol SI 2:23-25. http://www.sspm.org/smgp/ homeindex/forschungf/2020/Schapowal.pdf

Semwal DK, Semwal RB, Combrinck S, Viljoen A (2016) Myricetin: a dietary molecule with diverse biological activities. Nutrients 8:90. https://doi.org/10.3390/nu8020090

Si L, Meng K, Tian Z, Sun J, Li H, Zhang Z, Soloveva V, Li H, Fu G, Xia Q, Xiao S (2018) Triterpenoids manipulate a broad range of virushost fusion via wrapping the HR2 domain prevalent in viral envelopes. Sci Adv 4:eaau8408. https://doi.org/10.1126/sciadv.aau8408

Simmons G, Bertram S, Glowacka I, Steffen I, Chaipan C, Agudelo J, Lu K, Rennekamp AJ, Hofmann H, Bates P, Pöhlmann S (2011) Different host cell proteases activate the SARS-coronavirus spikeprotein for cell-cell and virus-cell fusion. Virology 413:265-274. https://doi.org/10.1016/j.virol.2011.02.020

Simmons G, Gosalia DN, Rennekamp AJ, Reeves JD, Diamond SL, Bates P (2005) Inhibitors of cathepsin L prevent severe acute respiratory syndrome coronavirus entry. Proc Natl Acad Sci U S A 102: 11876-11881. https://doi.org/10.1073/pnas.0505577102

Tahir ul Qamar M, Alqahtani SM, Alamri MA, Chen LL (2020) Structural basis of SARS-CoV-2 3CL ${ }^{\text {pro }}$ and anti-COVID-19 drug discovery from medicinal plants. J Pharm Anal 10:313-319. https:// doi.org/10.1016/j.jpha.2020.03.009

Theisen LL, Muller CP (2012) EPs® 7630 (Umckaloabo®), an extract from Pelargonium sidoides roots, exerts anti-influenza virus activity in vitro and in vivo. Antivir Res 94:147-156. https://doi.org/10. 1016/j.antiviral.2012.03.006

Vellingiri B, Jayaramayya K, Iyer M, Narayanasamy A, Govindasamy V, Giridharan B, Ganesan S, Venugopal A, Venkatesan D, Ganesan H, 
Rajagopalan (2020) COVID-19: a promising cure for the global panic. Sci Total Environ 725:138277. https://doi.org/10.1016/j. scitotenv.2020.138277

Wan Y, Shang J, Graham R, Baric RS, Li F (2020) Receptor recognition by the novel coronavirus from Wuhan: an analysis based on decadelong structural studies of SARS coronavirus. J Virol 94:e0127e00120. https://doi.org/10.1128/JVI.00127-20

Wang J, Chen X, Wang W, Zhang Y, Yang Z, Jin Y, Ge HM, Li E, Yang G (2013) Glycyrrhizic acid as the antiviral component of Glycyrrhiza uralensis Fisch. against coxsackievirus A16 and enterovirus 71 of hand foot and mouth disease. J Ethnopharmacol 147: 114-121. https://doi.org/10.1016/j.jep.2013.02.017

Wang L, Bao BB, Song GQ, Chen C, Zhang XM, Lu W, Wang Z, Cai Y, Li S, Fu S, Song FH (2017) Discovery of unsymmetrical aromatic disulfides as novel inhibitors of SARS-CoV main protease: chemical synthesis, biological evaluation, molecular docking and 3DQSAR study. Eur J Med Chem 137:450-461. https://doi.org/10. 1016/j.ejmech.2017.05.045

Wang M, Cao R, Zhang L, Yang X, Liu J, Xu M, Shi Z, Hu Z, Zhong W, Xiao G (2020a) Remdesivir and chloroquine effectively inhibit the recently emerged novel coronavirus $(2019-\mathrm{nCoV})$ in vitro. Cell Res 30:269-271. https://doi.org/10.1038/s41422-020-0282-0

Wang N, Shang J, Jiang S, Du L (2020b) Subunit vaccines against emerging pathogenic human coronaviruses. Front Microbiol 11:298. https://doi.org/10.3389/fmicb.2020.00298

Wang Q, Quan Q, Zhou X, Zhu Y, Lan Y, Li S, Yu Y, Cheng Z (2014) A comparative study of Lonicera japonica with related species: morphological characteristics, ITS sequences and active compounds. Biochem Syst Ecol 54:198-207. https://doi.org/10.1016/j.bse. 2014.02.002

Wen CC, Kuo YH, Jan JT, Liang PH, Wang SY, Liu HG, Lee CK, Chang ST, Kuo CJ, Lee SS, Hou CC (2007) Specific plant terpenoids and lignoids possess potent antiviral activities against severe acute respiratory syndrome coronavirus. J Med Chem 50:4087-4095. https:// doi.org/10.1021/jm070295s

Wen CC, Shyur LF, Jan JT, Liang PH, Kuo CJ, Arulselvan P, Wu JB, Kuo SC, Yang NS (2011) Traditional Chinese medicine herbal extracts of Cibotium barometz, Gentiana scabra, Dioscorea batatas, Cassia tora, and Taxillus chinensis inhibit SARS-CoV replication. J Tradit Complement Med 1:41-50. https://doi.org/10.1016/S22254110(16)30055-4

Wong SS, Yuen KY (2008) The management of coronavirus infections with particular reference to SARS. J Antimicrob Chemother 62: 437-441. https://doi.org/10.1093/jac/dkn243

Wu C, Liu Y, Yang Y, Zhang P, Zhong W, Wang Y, Wang Q, Xu Y, Li M, Li X, Zheng M (2020) Analysis of therapeutic targets for SARSCoV-2 and discovery of potential drugs by computational methods. Acta Pharm Sin B 10:766-788. https://doi.org/10.1016/j.apsb.2020. 02.008

Wu JG, Peng W, Yi J, Wu YB, Chen TQ, Wong KH, Wu JZ (2014) Chemical composition, antimicrobial activity against Staphylococcus aureus and a pro-apoptotic effect in SGC-7901 of the essential oil from Toona sinensis (A. Juss.) Roem. leaves. J Ethnopharmacol 154:198-205. https://doi.org/10.1016/j.jep.2014. 04.002

Wu T, Yang X, Zeng X, Poole P (2008) Traditional Chinese medicine in the treatment of acute respiratory tract infections. Respir Med 102: 1093-1098. https://doi.org/10.1016/j.rmed.2008.03.015

Xiao PG, Wang YY, Chen HS (2003) Some research clues on Chinese herbal medicine for SARS prevention and treatment. China J Chin Mater Med 28:481-483 https://pubmed.ncbi.nlm.nih.gov/ 15015319

Yang CW, Chang HY, Lee YZ, Hsu HY, Lee SJ (2018) The cardenolide ouabain suppresses coronaviral replication via augmenting a $\mathrm{Na}+/$ K+-ATPase-dependent PI3K PDK1 axis signaling. Toxicol Appl Pharmacol 356:90-97. https://doi.org/10.1016/j.taap.2018.07.028
Yang Y, Islam MS, Wang J, Li Y, Chen X (2020) Traditional Chinese medicine in the treatment of patients infected with 2019-new coronavirus (SARS-CoV-2): a review and perspective. Int J Biol Sci 16: 1708. https://doi.org/10.7150/ijbs.45538

Yeh CF, Wang KC, Chiang LC, Shieh DE, Yen MH, San Chang J (2013) Water extract of licorice had anti-viral activity against human respiratory syncytial virus in human respiratory tract cell lines. J Ethnopharmacol 148:466-473. https://doi.org/10.1016/j.jep.2013. 04.040

Yu MS, Lee J, Lee JM, Kim Y, Chin YW, Jee JG, Keum YS, Jeong YJ (2012) Identification of myricetin and scutellarein as novel chemical inhibitors of the SARS coronavirus helicase, nsP13. Bioorg Med Chem Lett 22:4049-4054. https://doi.org/10.1016/j.bmcl.2012.04. 081

Zhang DH, Wu KL, Zhang X, Deng SQ, Peng B (2020) In silico screening of Chinese herbal medicines with the potential to directly inhibit 2019 novel coronavirus. J Integr Med 18:152-158. https://doi.org/ 10.1016/j.joim.2020.02.005

Zhang H, Zhou G, Zhi L, Yang H, Zhai Y, Dong X, Zhang X, Gao X, Zhu Y, He F (2005) Association between mannose-binding lectin gene polymorphisms and susceptibility to severe acute respiratory syndrome coronavirus infection. J Infect Dis 192:1355-1361. https:// doi.org/10.1086/491479

Zhang P, Liu X, Liu H, Wang W, Liu X, Li X, Wu X (2018) Astragalus polysaccharides inhibit avian infectious bronchitis virus infection by regulating viral replication. Microb Pathog 114:124-128. https:// doi.org/10.1016/j.micpath.2017.11.026

Zhang T, Chen D (2008) Anticomplementary principles of a Chinese multiherb remedy for the treatment and prevention of SARS. J Ethnopharmacol 117:351-361. https://doi.org/10.1016/j.jep.2008. 02.012

Zhang X, Ao Z, Bello A, Ran X, Liu S, Wigle J, Kobinger G, Yao X (2016) Characterization of the inhibitory effect of an extract of Prunella vulgaris on Ebola virus glycoprotein (GP)-mediated virus entry and infection. Antivir Res 127:20-31. https://doi.org/10.1016/ j.antiviral.2016.01.001

Zhang X, Hasoksuz M, Spiro D, Halpin R, Wang S, Stollar S, Janies D, Hadya N, Tang Y, Ghedin E, Saif L (2007) Complete genomic sequences, a key residue in the spike protein and deletions in nonstructural protein $3 b$ of US strains of the virulent and attenuated coronaviruses, transmissible gastroenteritis virus and porcine respiratory coronavirus. Virol 358:424-435. https://doi.org/10.1016/j. virol.2006.08.051

Zhong J, Cui X, Shi Y, Gao Y, Cao H (2013) Antiviral activity of Jinchai capsule against influenza virus. J Tradit Chin Med 33:200-204. https://doi.org/10.1016/S0254-6272(13)60125-9

Zhou N, Pan T, Zhang J, Li Q, Zhang X, Bai C, Huang F, Peng T, Zhang J, Liu C, Tao L (2016) Glycopeptide antibiotics potently inhibit cathepsin L in the late endosome/lysosome and block the entry of Ebola virus, Middle East respiratory syndrome coronavirus (MERS$\mathrm{CoV}$ ), and severe acute respiratory syndrome coronavirus (SARSCoV). J Biol Chem 291:9218-9232. https://doi.org/10.1074/jbc. M116.716100

Zhou P, Yang XL, Wang XG, Hu B, Zhang L, Zhang W, Si HR, Zhu Y, Li B, Huang CL, Chen HD (2020a) A pneumonia outbreak associated with a new coronavirus of probable bat origin. Nature 579:270 273. https://doi.org/10.1038/s41586-020-2012-7

Zhou Y, Agudelo J, Lu K, Goetz DH, Hansell E, Chen YT, Roush WR, McKerrow J, Craik CS, Amberg SM, Simmons G (2011) Inhibitors of SARS-CoV entry-identification using an internally-controlled dual envelope pseudovirion assay. Antivir Res 92:187-194. https://doi.org/10.1016/j.antiviral.2011.07.016

Zhou Y, Hou Y, Shen J, Huang Y, Martin W, Cheng F (2020b) Networkbased drug repurposing for novel coronavirus 2019-nCoV/SARSCoV-2. Cell Discovery 6:1-18. https://doi.org/10.1038/s41421020-0153-3 
Zhou Y, Lu K, Pfefferle S, Bertram S, Glowacka I, Drosten C, Pöhlmann S, Simmons G (2010) A single asparagine-linked glycosylation site of the severe acute respiratory syndrome coronavirus spike glycoprotein facilitates inhibition by mannose-binding lectin through multiple mechanisms. J Virol 84:8753-8764. https://doi.org/10. 1128/JVI.00554-10

Zhuang W, Fan Z, Chu Y, Wang H, Yang Y, Wu L, Sun N, Sun G, Shen Y, Lin X, Guo G (2020) Chinese patent medicines in the treatment of coronavirus disease 2019 (COVID-19) in China. Front Pharmacol 11:1066. https://doi.org/10.3389/fphar.2020.01066

Zhuang M, Jiang H, Suzuki Y, Li X, Xiao P, Tanaka T, Ling H, Yang B, Saitoh H, Zhang L, Qin C (2009) Procyanidins and butanol extract of cinnamomi cortex inhibit SARS-CoV infection. Antivir Res 82: 73-81. https://doi.org/10.1016/j.antiviral.2009.02.001 